\title{
Branchial $\mathrm{NH}_{4}{ }^{+}$-dependent acid-base transport mechanisms and energy metabolism of squid (Sepioteuthis lessoniana) affected by seawater acidification
}

Marian Y Hu', Ying-Jey Guh', Meike Stumpp', Jay-Ron Lee', Ruo-Dong Chen ${ }^{1}$, Po-Hsuan Sung ${ }^{2}$, Yu-Chi Chen², Pung-Pung Hwang ${ }^{1}$ and Yung-Che Tseng ${ }^{2^{*}}$

\begin{abstract}
Background: Cephalopods have evolved strong acid-base regulatory abilities to cope with $\mathrm{CO}_{2}$ induced pH fluctuations in their extracellular compartments to protect gas transport via highly pH sensitive hemocyanins. To date, the mechanistic basis of branchial acid-base regulation in cephalopods is still poorly understood, and associated energetic limitations may represent a critical factor in high power squids during prolonged exposure to seawater acidification.

Results: The present work used adult squid Sepioteuthis lessoniana to investigate the effects of short-term (few hours) to medium-term (up to $168 \mathrm{~h}$ ) seawater acidification on pelagic squids. Routine metabolic rates, $\mathrm{NH}_{4}^{+}$excretion, extracellular acid-base balance were monitored during exposure to control $(\mathrm{pH}$ 8.1) and acidified conditions of $\mathrm{pH}$ 7.7 and 7.3 along a period of $168 \mathrm{~h}$. Metabolic rates were significantly depressed by $40 \%$ after exposure to $\mathrm{pH} 7.3$ conditions for $168 \mathrm{~h}$. Animals fully restored extracellular $\mathrm{pH}$ accompanied by an increase in blood $\mathrm{HCO}_{3}{ }^{-}$levels within 20 hours. This compensation reaction was accompanied by increased transcript abundance of branchial acid-base transporters including V-type $\mathrm{H}^{+}$-ATPase (VHA), Rhesus protein (RhP), $\mathrm{Na}^{+} / \mathrm{HCO}_{3}{ }^{-}$cotransporter (NBC) and cytosolic carbonic anhydrase (CAc). Immunocytochemistry demonstrated the sub-cellular localization of $\mathrm{Na}^{+} / \mathrm{K}^{+}$-ATPase (NKA), VHA in basolateral and $\mathrm{Na}^{+} / \mathrm{H}^{+}$-exchanger 3 (NHE3) and RhP in apical membranes of the ion-transporting branchial epithelium. Branchial VHA and RhP responded with increased mRNA and protein levels in response to acidified conditions indicating the importance of active $\mathrm{NH}_{4}^{+}$transport to mediate acid-base balance in cephalopods.

Conclusion: The present work demonstrated that cephalopods have a well developed branchial acid-base regulatory machinery. However, pelagic squids that evolved a lifestyle at the edge of energetic limits are probably more sensitive to prolonged exposure to acidified conditions compared to their more sluggish relatives including cuttlefish and octopods.
\end{abstract}

Keywords: Acid-base regulation, Invertebrate, Metabolism, Ocean acidification, Rh proteins

\footnotetext{
*Correspondence: yct@ntnu.edu.tw

${ }^{2}$ Department of Life Science, National Taiwan Normal University, Taipei City,

Taiwan

Full list of author information is available at the end of the article
}

\section{Biomed Central}

(C) 2014 Hu et al.; licensee BioMed Central Ltd. This is an Open Access article distributed under the terms of the Creative Commons Attribution License (http://creativecommons.org/licenses/by/4.0), which permits unrestricted use, distribution, and reproduction in any medium, provided the original work is properly credited. The Creative Commons Public Domain Dedication waiver (http://creativecommons.org/publicdomain/zero/1.0/) applies to the data made available in this article, unless otherwise stated. 


\section{Introduction}

$\mathrm{CO}_{2}$ induced acid-base disturbances are a unifying physiological phenomenon that all animals are confronted with. Depending on the degree of metabolic activity an organism generates metabolic $\mathrm{CO}_{2}$ leading to intra- and extra-cellular $p \mathrm{CO}_{2}$ fluctuations causing acid-base disturbances after the hydration of $\mathrm{CO}_{2}$ in body fluids. Cephalopods have probably evolved the highest physiological complexity among all invertebrate taxa. It is believed that convergent evolutionary features including sensory and locomotory abilities derived from the competition with fish for similar resources in the marine environment. As a trade off to their less efficient swimming mode and active lifestyle they have the highest metabolic rates among marine animals [1]. As a consequence cephalopods are confronted with strong metabolic $\mathrm{CO}_{2}$ induced temporal acid-base disturbances during jetting and fast swimming [2]. To accommodate strong temporal $\mathrm{CO}_{2}$ induced acid-base challenges cephalopods have evolved moderate to strong acid-base regulatory abilities to stabilize blood $\mathrm{pH}$ during exercise and hypercapnic exposure by accumulating up to $7 \mathrm{mM}$ $\mathrm{HCO}_{3}{ }^{-}[2,3]$. It is believed that well developed extracellular $\mathrm{pH}(\mathrm{pHe})$ regulatory abilities are an essential feature for cephalopods to protect their highly $\mathrm{pH}$ sensitive extracellular $\mathrm{O}_{2}$ transporting hemocyanins [4,5]. Oxygen affinity of the extracellular hemocyanin is inversely related to both, $\mathrm{pH}$ and $\mathrm{pCO}_{2}$ which is expressed by the Bohr effect [6]. The high pH sensitivity of squid hemocyanin is an important feature to efficiently load oxygen at the gill and unload in tissues. On one hand, high Bohr coefficients of cephalopods were proposed to be a critical physiological characteristic that would make cephalopods particularly sensitive to acid-base disturbances [7]. On the other hand well developed acid-base regulatory abilities were hypothesized to represent a unifying feature that makes ectothermic marine animals robust to seawater acidification as projected for the coming century [8]. Studies using adult cuttlefish could in fact demonstrate that these animals can tolerate exposure to $\mathrm{pH} 7.1$ over several weeks without compromising growth rates and even increase calcification rates of the internal cuttlebone [9]. Moreover the same study demonstrated that metabolic rates of cuttlefish exposed to decreased seawater $\mathrm{pH}$ of $7.1(0.6 \mathrm{kPa} \mathrm{CO} 2)$ remained unchanged along the experimental period of $24 \mathrm{~h}$. In contrast the pelagic squid Dosidicus gigas responded with depressed metabolic rates (31\%) and activity levels (45\%) in response to acute exposure to $0.1 \mathrm{kPa} \mathrm{CO}$ [1]. However, medium- to long-term (several days) acidification experiments using squids with a pelagic lifestyle are rare as these animals are extremely difficult to keep under laboratory conditions. Such experiments require large-scale experimental facilities with access to natural, high quality seawater. Recent research conducted with squid and cuttlefish embryonic stages which are easier to handle under laboratory conditions demonstrated that acidified conditions evoke a developmental delay associated with an increase in proton secretion activity [10]. The upregulation of acid-base regulatory genes including $\mathrm{Na}^{+} / \mathrm{H}^{+}$exchanger (NHE3), V-type $\mathrm{H}^{+}$-ATPase (VHA), Rhesus protein (RhP) and $\mathrm{Na}^{+} / \mathrm{HCO}_{3}{ }^{-}$cotransporter (NBC) expressed in epidermal ionocytes suggest that these transporters are key players of acid-base regulation in cephalopod early life stages. The current model for epidermal ionocytes of squid embryos denotes the presence of NHE3 in apical membranes whereas $\mathrm{Na}^{+} / \mathrm{K}^{+}$-ATPase (NKA) and VHA are localized in basolateral membranes. Proton secretion by epidermal ionocytes is sensitive to ethyl-isopropyl amiloride (EIPA) suggesting a central role of NHE proteins in proton secretion pathways. Less information is available for the branchial acid-base regulatory machinery of adult cephalopods. Earlier studies identified and localized acid-base transporters including NKA, VHA, NBC and carbonic anhydrase (CA) in specialized iontransporting cells of the cephalopod gill [11-13]. In contrast to fish and crustacean gills, the gill of decapod cephalopods is a highly folded epithelium consisting of two epithelial layers that line a blood sinus (Figure 1). The two epithelial layers are linked by pilaster cells, that interdigitate deeply with muscle cells differentiated on the basal lamina of the inner and the outer epithelium. The thin outer epithelium

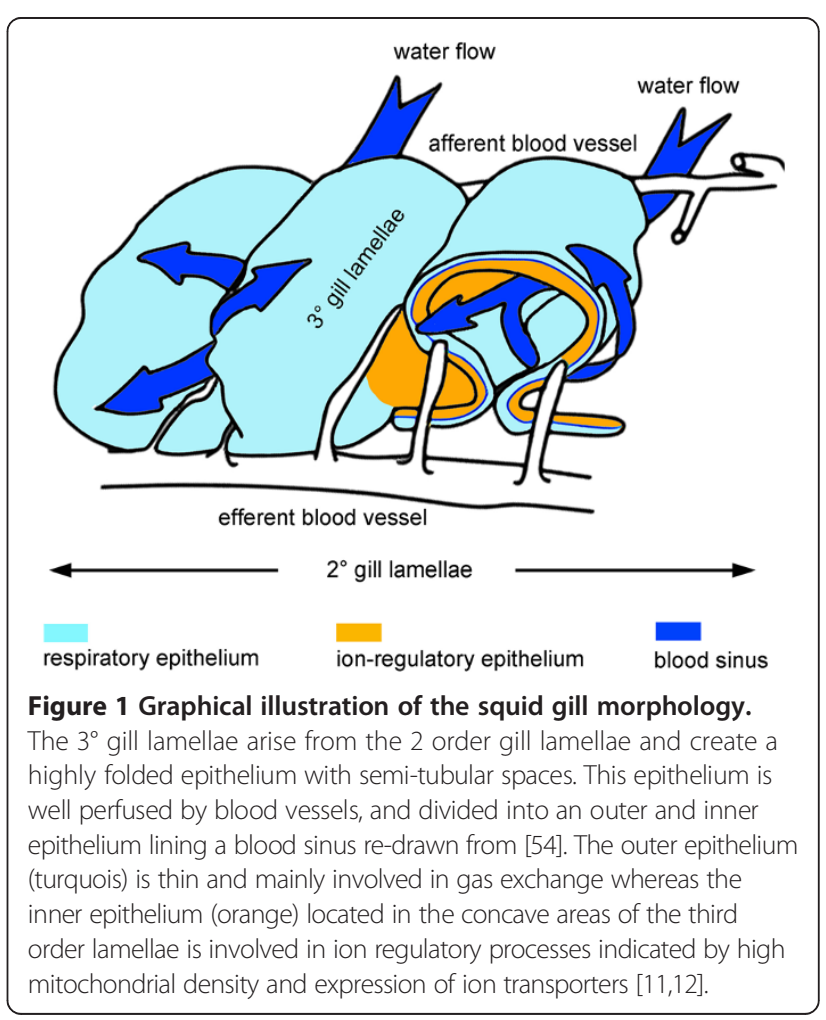


is mainly involved in respiratory processes, whereas the inner, mitochondria rich epithelium is responsible for ion regulation and, probably, nitrogen excretion [11,12,14].

In teleost fish acid-base regulating epithelia and organs have been extensively studied and the sub-cellular organization of ion transporters localized in mitochondriarich cells is well described e.g. [15-17]. Besides primary active proton extrusion mechanisms via VHA these models suggest an import of $\mathrm{HCO}_{3}{ }^{-}$and export of protons by secondary active transporters such as NHEs and $\mathrm{Na}^{+}$-dependent $\mathrm{HCO}_{3}{ }^{-}$transporters of the SLC4 solute transporter family energized by the NKA located in basolateral membranes. Although a large body of knowledge is available for teleosts, a comparatively small number of studies investigated acid-base and ion regulatory mechanisms in non-model invertebrates like mollusks, echinoderms and crustaceans. For the latter a number of studies exist with osmotic and acid-base regulatory mechanisms recently summarized by Henry et al. [18], demonstrating the complexity of ion-transport processes in gill epithelia of crustaceans. Although the picture seems more complete for osmoregulatory mechanisms in crustacean gill epithelia the mechanistic basis for acid-base regulation seems largely unexplored as well. Crustaceans were also characterized as strong acid-base regulators that are capable of accumulating high concentrations of $\mathrm{HCO}_{3}^{-}$ in their body fluids to buffer an excess of protons. It has been pharmacologically demonstrated that low $\mathrm{pH}$ conditions trigger the response of carbonic anhydrase (CA), apical VHA and basolateral $\mathrm{Na}^{+} / \mathrm{HCO}_{3}{ }^{-}$exchanger in perfused gills of the euryhaline crab Neohelice (Chasmagnathus) granulata [19]. Furthermore, NHEdependent acid-base regulation has been suggested in the blue crab that responded with an increase in $\mathrm{Na}^{+}$uptake when exposed to hypercapnic conditions of $1 \% \mathrm{CO}_{2}$ [20]. Pharmacological studies suggested the presence of NHEs and VHA in apical membranes of crustacean gills. Another potential model for proton equivalent secretion in crustacean gills has been proposed by Weihrauch and colleagues [21], suggesting trapping of $\mathrm{NH}_{4}{ }^{+}$in VHA-rich vesicles and subsequent exocytosis across the apical membrane. The entrance of $\mathrm{NH}_{4}{ }^{+}$across the basolateral membrane is achieved by the NKA, which may also accept $\mathrm{NH}_{4}{ }^{+}$as a substrate or by $\mathrm{K}^{+} / \mathrm{NH}_{4}{ }^{+}$channels. In this context a Rhesus protein (RhP) cloned from Dungeness crab Metacarcinus magister is proposed to be substantially involved in branchial $\mathrm{NH}_{3} / \mathrm{NH}_{4}{ }^{+}$regulation during exposure to a high $\mathrm{NH}_{4}{ }^{+}$environment [22].

Interestingly, a range of marine invertebrates including bivalves, echinoderms and crustaceans responded with increased $\mathrm{NH}_{4}{ }^{+}$excretion rates when exposed to acidified conditions [23-26]. It has been suggested that this phenomenon may be associated with enhanced protein metabolism to fuel increased acid-base regulatory costs, and/or may support $\mathrm{NH}_{4}{ }^{+}$based proton equivalent secretion to mediate $\mathrm{pH}$ homeostasis. In vertebrates, the excretion of $\mathrm{NH}_{4}{ }^{+}$mediated by Rhesus $\mathrm{C}$ glycoprotein (Rhcg) and Rhesus B glycoprotein (Rhbg) in combination with NHE3 or VHA located in apical membranes has been demonstrated to be connected to net export of protons [27-29]. Thus, it can be hypothesized that $\mathrm{NH}_{4}{ }^{+}$-based proton secretion also represents a fundamental $\mathrm{pH}$ regulatory pathway, probably connected to a reallocation of energy sources, in marine invertebrates.

The present work aims at identifying and characterizing the acid-base regulatory mechanisms by looking at $\mathrm{H}^{+}$ extrusion and $\mathrm{HCO}_{3}{ }^{-}$import pathways in gill epithelia of adult squid. Additionally, metabolism and excretion are monitored during exposure to acidified conditions, which are important indices for altered energetic features potentially associated with acid-base regulatory efforts. Immunocytochemical techniques in combination with gene expression analyses were applied in order to study the branchial acid-base regulatory machinery. It can be hypothesized that similar to the situation in embryonic epidermal ionocytes, the branchial acid-base regulatory machinery of adult squid involves ion-transporters including NHE3, V-type $\mathrm{H}^{+}$-ATPase, Rh-Protein as well as CAc and $\mathrm{NBC}$, which allows the animal to cope with $\mathrm{CO}_{2}$ induced acid-base disturbances. In this context special attention has been dedicated to the potential role of $\mathrm{RhP}$ in mediating $\mathrm{pH}$ homeostasis during environmental hypercapnia by supporting proton equivalent transport across membranes. A potential coupling of $\mathrm{NH}_{3}$ and $\mathrm{H}^{+}$excretion/secretion is proposed, which may represent a fundamental pathway of $\mathrm{pH}$ regulation in marine ammonotelic organisms.

\section{Results}

\section{Metabolic rates and $\mathrm{NH}_{4}{ }^{+}$excretion}

Metabolic rates of squid Sepiteuthis lessoniana kept under control conditions were $25.20 \pm 4.97 \mu \mathrm{mol} \mathrm{O} \mathrm{O}^{-1}$ $\mathrm{g}_{\mathrm{FM}}{ }^{-1}$ (Figure $2 \mathrm{~A}+\mathrm{B}$ ). During short-term exposure to hypercapnic conditions at the time point of $20 \mathrm{~h}$ no difference in metabolic rates was observed for animals from different treatment groups. However, after mediumterm exposure to $\mathrm{pH} \mathrm{7.3,} \mathrm{at} \mathrm{the} \mathrm{time} \mathrm{point} \mathrm{of} 168 \mathrm{~h}$, metabolic rates were significantly decreased down to $16.3 \pm$ $0.79 \mu \mathrm{mol} \mathrm{O} \mathrm{O}^{-1} \mathrm{~g}_{\mathrm{FM}}{ }^{-1}$ compared to animals from the pH 8.1 treatment (Figure 2B). Despite a positive correlation between acidified conditions and $\mathrm{NH}_{4}{ }^{+}$excretion rates no significant differences $(\mathrm{p}=0.28)$ were found between control and low $\mathrm{pH}$ treated animals after $20 \mathrm{~h}$ (Figure 2C). When exposed to acidified conditions for $168 \mathrm{~h} \mathrm{NH}_{4}{ }^{+}$excretion rates were decreased although statistical analysis could not demonstrate a significant effect $(\mathrm{p}=0.155)$ in $\mathrm{pH} 7.3$ treated animals (Figure 2D). No change in $\mathrm{O}: \mathrm{N}$ ratio were observed in low $\mathrm{pH}$ treated animals during both, short- and mediumterm exposure to acidified conditions (Figure 2E $+\mathrm{F}$ ). 


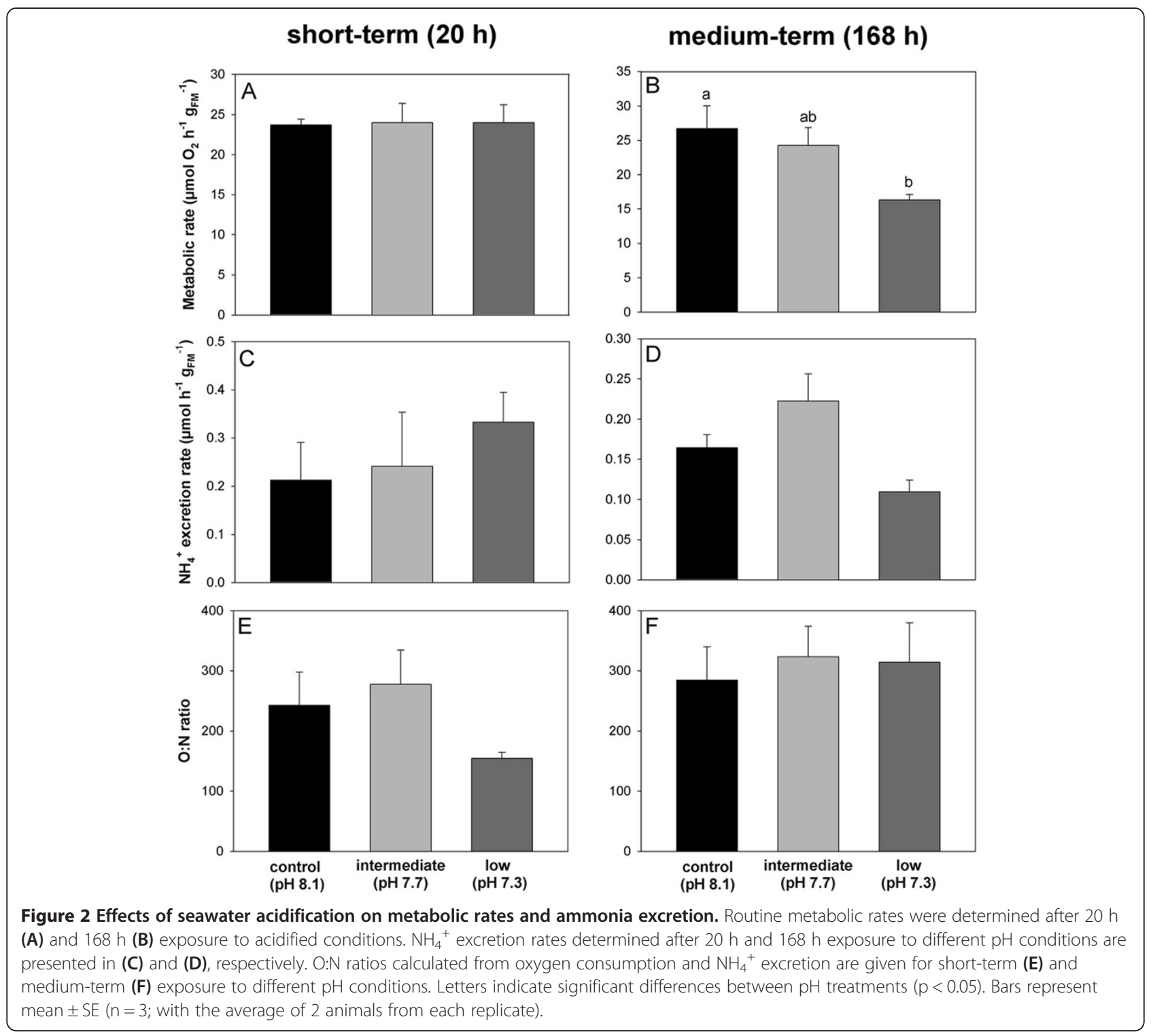

\section{Extracellular acid-base status}

Extracellular $\mathrm{pH}$ (pHe) measured in venous blood from control animals was $7.34 \pm 0.07$ (Figure 3A). In response to acidified conditions of $\mathrm{pH} 7.7$ and $7.3 \mathrm{pHe}$ dropped by approximately 0.05 to $0.08 \mathrm{pH}$ units compared to control animals at the time point of $6 \mathrm{~h}$. pHe was quickly restored after $20 \mathrm{~h}$ and maintained stable between pH 7.35 and $\mathrm{pH} 7.4$ in both, control and low $\mathrm{pH}$ treated animals. Blood $\mathrm{HCO}_{3}{ }^{-}$levels were found to range from 2.24 to $2.68 \mathrm{mM}$ in control animals along the incubation period of $168 \mathrm{~h}$ (Figure 3B). In response to acidified conditions of pH 7.3 blood $\mathrm{HCO}_{3}{ }^{-}$levels were significantly increased by $2 \mathrm{mM}$ along the entire incubation period of $168 \mathrm{~h}$. Only at the $168 \mathrm{~h}$ time point blood $\mathrm{HCO}_{3}{ }^{-}$levels were found to be increased by approximately $1 \mathrm{mM}$ in pH 7.7 treated animals (Figure 3B).
Blood $p \mathrm{CO}_{2}$ levels ranged from 0.32 to $0.39 \mathrm{kPa}$ in control animals along the incubation period of $168 \mathrm{~h}$ (Figure 3C). In response to $\mathrm{CO}_{2}$ induced seawater acidification, blood $p \mathrm{CO}_{2}$ levels increased to peak values of $0.51 \pm 0.08 \mathrm{kPa}$ and $0.71 \pm 0.29 \mathrm{kPa}$ in $\mathrm{pH} 7.7$ and $\mathrm{pH} 7.3$ treated animals, respectively (Figure 3C). Acid-base compensatory characteristics are depicted in Figure 4 using a davenport diagram. For clarity reasons the two low $\mathrm{pH}$ treatments were separated into two graphs. Figure $4 \mathrm{~A}$ compares control $(\mathrm{pH} 8.1)$ to intermediate $(\mathrm{pH} 7.7)$ treated animals whereas Figure 4B compares control to low (pH 7.3) $\mathrm{pH}$ treated animals. In response to $6 \mathrm{~h}$ exposure to acidified conditions a slight initial respiratory acidosis was observed in both treatments. However, pHe is fully restored at the time point of $20 \mathrm{~h}$ of low $\mathrm{pH}$ exposure and is maintained along the entire period of $168 \mathrm{~h}$. 


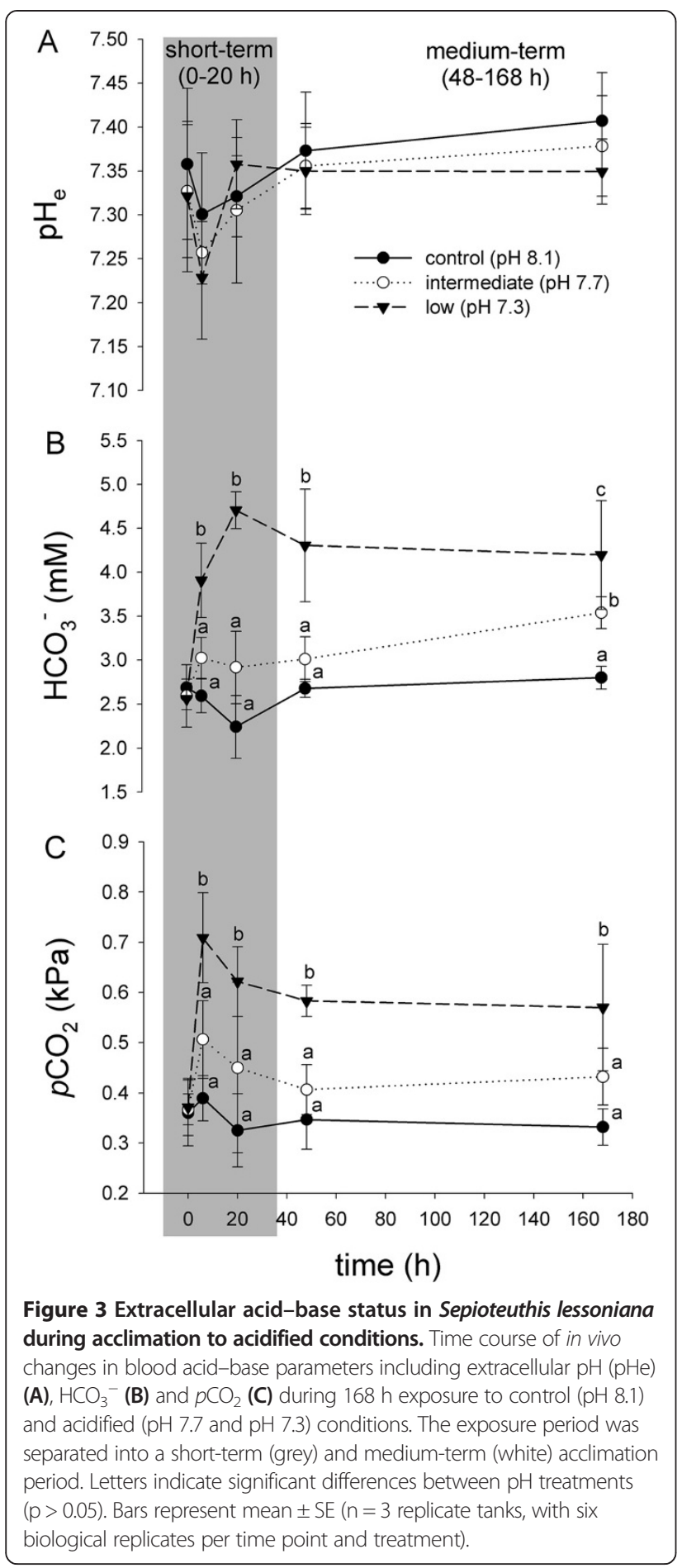

\section{Localization of acid-base relevant transporters in gill epithelia}

Using antibodies specifically designed for cephalopod VHA, NHE3 and RhP the sub-cellular localization of these transporters in gill epithelia has been clarified (Figure 5). Using double staining of NKA and NHE3 high concentrations of NKA in basolateral and NHE3 in apical membranes was demonstrated for cells belonging to the inner (concave) ion-transporting epithelium of the cephalopod gill (Figure 5A). The basolateral signal of NKA can be characterized by deep infoldings into the cell cytoplasm of ionocytes. In contrast, the apical signal of NHE3 can be characterized by a sharp lining along the apical membrane. Both signals were clearly co-localized in cells belonging to the ion-transporting inner part of the gill epithelium. Double staining of NHE3 and VHA demonstrated the localization of VHA in basolateral membranes of the ion-transporting inner epithelium. Moreover VHA immunoractivity was also observed in pilaster cells spanning between the outer and the inner epithelium (Figure 5B+D). Using an antibody specifically designed against the squid RhP that was cloned in a previous study [10] positive immunoreactivity has been demonstrated in apical membranes of cells belonging to the inner ion-transporting epithelium (Figure 5C). Negative controls by omitting the primary antibody demonstrated no unspecific fluorescence signal (Additional file 1: Figure S1). Western blot analyses of the four antibodies used in this study demonstrate specific immunoreactivity with proteins including NKA (115 kDa), NHE3 (90 kDa), VHA (65 kDa) and RhP $(50 \mathrm{kDa})$ (Figure 5E).

\section{NKA and VHA activity}

Enzyme activities of NKA measured in gill homogenates of control animals at the time point of $0 \mathrm{~h}$ were $150 \pm 29.17 \mu \mathrm{mol} \mathrm{ATP} \mathrm{h}^{-1} \mathrm{~g}_{\mathrm{FM}}{ }^{-1}$. After $168 \mathrm{~h} \mathrm{NKA}$ maximum activities decreased down to $43.3 \pm 12.3 \mu \mathrm{mol}$ ATP $\mathrm{h}^{-1} \mathrm{~g}_{\mathrm{FM}}{ }^{-1}$ (Figure 6A). Along the entire experimental period no significant differences $(\mathrm{p}=0.342)$ were observed between control and low $\mathrm{pH}$ treated animals. Enzyme activities of VHA measured in gill homogenates of control animals at the time point of $0 \mathrm{~h}$ were $172 \pm 39.40 \mu \mathrm{mol}$ ATP $\mathrm{h}^{-1} \mathrm{~g}_{\mathrm{FM}}{ }^{-1}$, and control activities remained relatively stable over the entire incubation period of $168 \mathrm{~h}$ (Figure 6B). Despite a tendency $(\mathrm{p}=0.061)$ of increased activities in gills of $\mathrm{pH} 7.3$ treated animals at the time point of $20 \mathrm{~h}$ no significant differences were observed between control and low $\mathrm{pH}$ treated animals.

\section{Protein concentrations}

Determination of relative protein concentrations in gill homogenates at the time point of $20 \mathrm{~h}$ (short-term) demonstrated that NKA protein concentration normalized to $\beta$-actin had no statistical difference between $\mathrm{pH}$ treatments (Figure 7A). VHA protein concentrations in gill tissues were significantly increased by $54 \%(\mathrm{p}=0.009)$ and $47 \%(\mathrm{p}=0.033)$ in response to low $\mathrm{pH}$ treatments of pH 7.7 and 7.3, respectively (Figure 7B). No change in relative protein concentrations was observed for NHE3 in gill homogenates (Figure 7C). Finally, RhP protein 

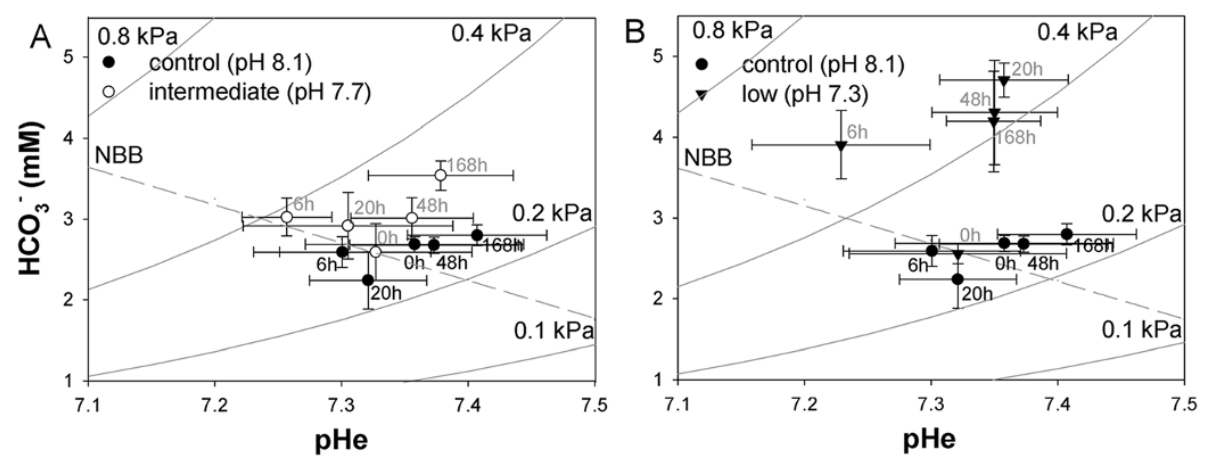

Figure $4 \mathrm{pH}$-bicarbonate (Davenport) diagram demonstrating the time course of acid-base compensation. Blood acid-base status was determined along the experimental period of $168 \mathrm{~h}$ for animals exposed to control ( $\mathrm{pH} 8.1)$, intermediate (pH 7.7) and low (pH 7.3) conditions. For clarity reasons the intermediate $\mathrm{pH}(\mathbf{A})$ and low pH (B) treatments are presented in two separate graphs, including control acid-base conditions along the incubation period of $168 \mathrm{~h}$. The non-bicarbonate buffer line for Sepioteuthis lessoniana is indicated by a grey dashed line and was adopted from Lykkeboe and Johansen [39]. The solid curved lines represent $p \mathrm{CO}_{2}$ isopleths. Numbers in brackets indicate sampling time points. Bars represent mean \pm SE $(n=3$ replicate tanks, with six biological replicates per time point and treatment).

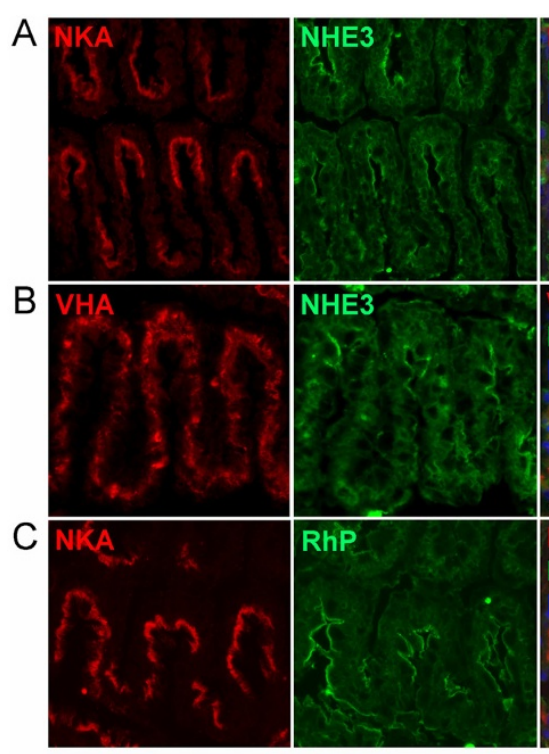

$\mathrm{E}$

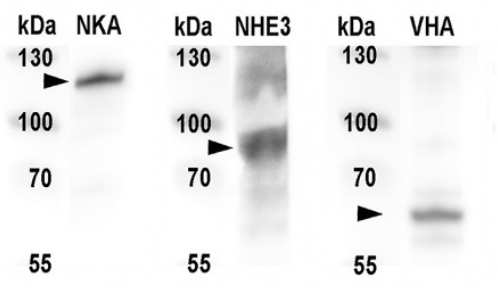

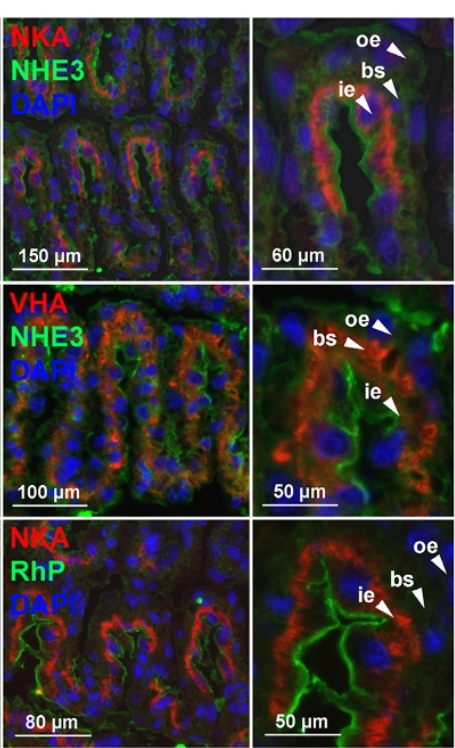

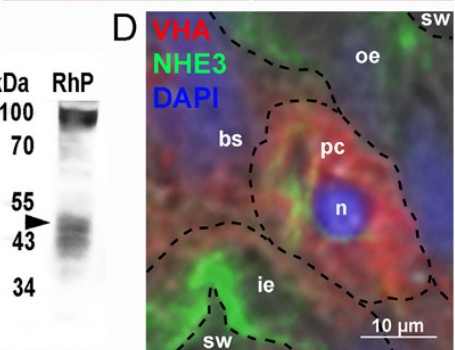

Figure $\mathbf{5}$ Localization of acid-base transporters in gill epithelia of squid Sepioteuthis lessoniana. Immunohistochemical analyses demonstrated co-localization of acid-base transporters including $\mathrm{Na}^{+} / \mathrm{K}^{+}$-ATPase (NKA), $\mathrm{Na}^{+} / \mathrm{H}^{+}$-exchanger 3 (NHE3), $\mathrm{V}$-type $\mathrm{H}^{+}$-ATPase $(\mathrm{VHA})$ and Rhesus protein (RhP) in the ion-transporting epithelium of the squid gill. NKA is located in basolateral membranes whereas the NHE3 specific antibody shows positive immunoreactivity in apical membranes (A). VHA is located in basolateral membranes as well as pillar-cells spanning through the blood sinus (B). The RhP specific antibody shows positive immunoreactivity in apical membranes of the inner, ion-transporting branchial epithelium (C). High magnification image of a pilaster (pillar) cell showing positive VHA immunoreactivity. Dashed lines indicate the contour of the cell and the epithelial cells lining the blood sinus (D). Western blot analyses using gill homogenates, indicating specific immune-reactivity of the different antibodies with proteins in the predicted size range (indicated by arrows) (E). blood sinus (bs); inner epithelium (ie); outer epithelium (oe). 


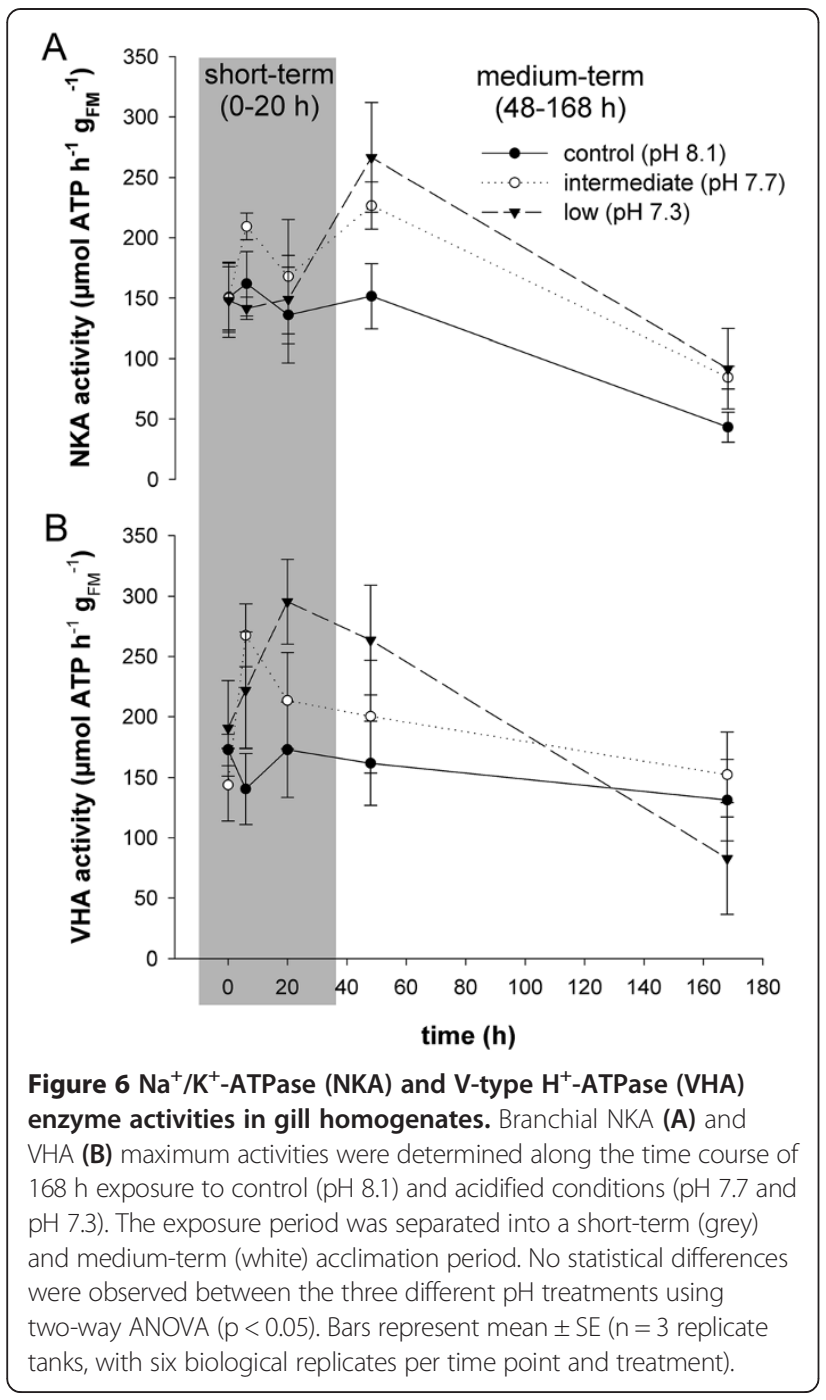

concentrations were significantly increased by $40 \%$ in response to the $\mathrm{pH} 7.3$ treatment $(\mathrm{p}=0.045)$ (Figure 7 ).

\section{Gene expression}

Gene expression studies demonstrated differences along the incubation period of $168 \mathrm{~h}$ in control and low $\mathrm{pH}$ treated animals. Despite an up regulation pattern of NKA and NHE3 during short-term exposure to acidified conditions no significant differences $(p=0.1$ for NKA and $\mathrm{p}=0.15$ for NHE3) were detected between control and low $\mathrm{pH}$ treatments (Figure 8). In contrast, significant up regulations were detected for the genes VHA, RhP and NBC between control and low $\mathrm{pH}$ treated animals. VHA expression increased rapidly at the time point of $6 \mathrm{~h}$ in $\mathrm{pH} 7.7$ and $\mathrm{pH} 7.3$ treated animals by $53 \%$ and $71 \%$, respectively (Figure 8 ). At this time point statistically significant differences for VHA transcript levels were found between $\mathrm{pH} 8.1$ and $\mathrm{pH} 7.3(\mathrm{p}<0.001)$ and between $\mathrm{pH} 7.7$ and $\mathrm{pH} 7.3$ $(\mathrm{p}=0.032)$ treatments. Although no significant differences were detected for the following time points VHA transcript levels of low $\mathrm{pH}$ treated animals were elevated by approximately $30 \%$ compared to control levels along the entire period of $168 \mathrm{~h}$ (Figure 8). In low $\mathrm{pH}$ treated animals RhP increased transcript levels during both short-term and medium-term exposure to acidified conditions. In response to $48 \mathrm{~h}$ exposure to acidified conditions RhP transcript levels were significantly increased by $50 \%(\mathrm{p}<0.001)$ and $55 \%(\mathrm{p}=0.02)$ in $\mathrm{pH} 7.7$ and $\mathrm{pH} 7.3$ treated animals, respectively when compared to $\mathrm{pH} 8.1$ conditions (Figure 8 ). This significant increase of RhP mRNA levels in low pH treated animals compared to control animals was still evident after $168 \mathrm{~h}$ in $\mathrm{pH} 7.7$ ( $\mathrm{p}=0.038)$ and $\mathrm{pH} 7.3(\mathrm{p}=0.025)$, respectively. Compared to control animals NBC was significantly up regulated at $48 \mathrm{~h}$ in $\mathrm{pH} 7.7$ and $\mathrm{pH} 7.3$ treated animals by $55 \%$ $(\mathrm{p}<0.001)$ and $33 \%(\mathrm{p}=0.002)$, respectively (Figure 8$)$. No statistical differences for NBC mRNA levels were found between control and low $\mathrm{pH}$ treated animals during medium-term exposure of $168 \mathrm{~h}$. During short-term (6 h) and medium-term (168 h) exposure to acidified conditions carbonic anhydrase transcript levels were significantly increased $(\mathrm{p}<0.001)$ in gills of squid exposed to $\mathrm{pH} 7.7$ conditions when compared to control ( $\mathrm{pH}$ 8.1) animals (Figure 8). No significant differences were observed for branchial CAc transcript levels between control and pH 7.3 treated animals.

\section{Discussion}

\section{Metabolism and excretion}

The present work demonstrated that routine metabolic and $\mathrm{NH}_{4}{ }^{+}$excretion rates in squid Sepioteuthis lessoniana are comparable to those determined for other squid and cuttlefish species [1,30-33]. While $\mathrm{NH}_{4}{ }^{+}$excretion rates were not significantly affected by acidified conditions, metabolic rates were reduced upon prolonged exposure to $\mathrm{pH}$ 7.3. To date only a few studies investigated the effects of acidified conditions on metabolic responses in cephalopods. One study using the pelagic squid Dosidicus gigas demonstrated that in response to acute (several minutes) $\mathrm{CO}_{2}$ induced acidified conditions of $\mathrm{pH} 7.6\left(0.1 \mathrm{kPa} p \mathrm{CO}_{2}\right)$ animals respond with depressed metabolic rates accompanied by decreased activity levels [1]. In contrast, routine metabolic rates of the demersal cuttlefish Sepia officinalis remained unaffected by $\mathrm{CO}_{2}$ induced seawater acidification down to $\mathrm{pH} 7.1$ during acute $(24 \mathrm{~h})$ exposure [9]. Differential responses observed for the three cephalopod species can be attributed to their very different life styles and abilities to swim and maintain neutral to positive buoyancy in the water column. Migratory pelagic squids like D. gigas swim and maintain positive buoyancy by continuously jetting water through their funnel, whereas $S$. officinalis has a decoupled 

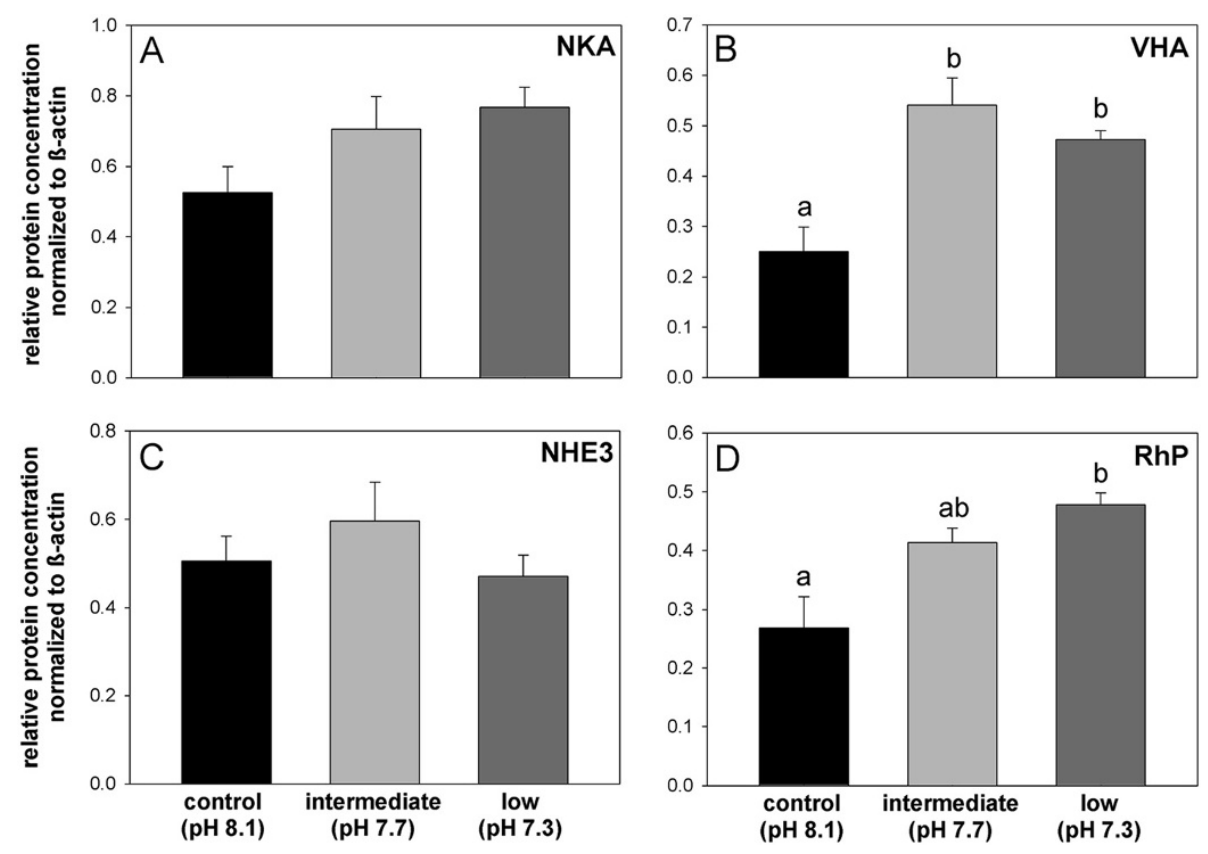

Figure 7 Relative protein concentrations of branchial acid-base transporters. Branchial protein concentrations of acid-base transporters including $\mathrm{Na}^{+} / \mathrm{K}^{+}$-ATPase (NKA) (A), V-type $\mathrm{H}^{+}$-ATPase (VHA) (B), Na $/ \mathrm{H}^{+}$-exchanger 3 (NHE3) (C) and Rhesus protein (RhP) (D) determined after $20 \mathrm{~h}$ exposure to different $\mathrm{pH}$ conditions. Protein concentrations were normalized to $ß$-actin protein concentrations as an internal control. Letters indicate significant differences between $\mathrm{pH}$ treatments $(p<0.05)$. Bars represent mean $\pm S E(n=3$; with the average of 2 animals from each replicate).

swimming mode, by using jetting and fin undulation. Additionally, Sepia spp. have a gas filled cuttlebone to control buoyancy without continuous muscular activity that significantly increases locomotor efficiency [34]. S. lessoniana is a large-finned pelagic squid that has evolved a partially decoupled swimming mode by additionally maintaining buoyancy using their enlarged fins running the full length of its mantle. Powerful pelagic squids that have no decoupled swimming mode need to spend a larger fraction of their energy budget to swim and to maintain neutral buoyancy $[34,35]$. This higher fraction of energy that is spent for maintaining buoyancy could be a critical factor leading to higher sensitivities. In fact, the energy budget of marine invertebrates has been demonstrated to be compromised by seawater acidification by shifting a larger fraction of energy towards compensatory processes (e.g. acid-base regulation) leading to less energy available for growth and development [23]. The fact that in the present work two individuals died after exposure to $\mathrm{pH} 7.3$ conditions for one week indicates a higher sensitivity towards acidified conditions than cuttlefish S. officinalis that survived with a five-fold increase in body mass during exposure to a seawater $\mathrm{pH}$ of 7.1 for 6 weeks [9]. It can be suggested that pelagic squids that evolved a life-style at the edge of energetic limitations, might react more sensitively to seawater acidification due to energetic limitations, compared to less "tuned" cuttlefish and octopus. To test this hypothesis, studies addressing the energetic costs of acid-base regulation in cephalopods will be an important future task.

\section{Acid-base regulation during seawater acidification}

The present work demonstrated that squid S. lessoniana can fully compensate for an extracellular acidosis evoked by seawater acidification up to $\mathrm{pH}$ 7.3. Stabilization of pHe is accompanied by an increase in blood $\mathrm{HCO}_{3}{ }^{-}$ levels, which is a conserved and efficient mechanism to counter a respiratory acidosis found in several taxa, including fish, crustaceans and cephalopods [2,3,18,36]. The hyperbolic increase in blood $\mathrm{HCO}_{3}^{-}$levels in response to a respiratory acidosis described for other powerful acid-base regulators is in general accordance to the findings for S. lessoniana e.g. [37,38]. Under control conditions venous $\mathrm{HCO}_{3}^{-}$levels of $\mathrm{S}$. lessoniana ( $2.5 \mathrm{mM})$ were found to be in the range as described for other cephalopod species including the squid Illex illecebrosus $(2.2 \mathrm{mM})$ and the cuttlefish Sepia officinalis (3.4 mM) [2,3]. An earlier study using the cuttlefish Sepia officinalis demonstrated control blood $\mathrm{HCO}_{3}^{-}$ levels of $3.4 \mathrm{mM}$ and a partial compensation of $\mathrm{pHe}$ via $\mathrm{HCO}_{3}^{-}$accumulation during exposure to environmental hypercapnia (0.6 $\left.\mathrm{kPa} p \mathrm{CO}_{2} ; \mathrm{pH} 7.1\right)$ [3]. In the same study it was suggested that a partial compensation of 


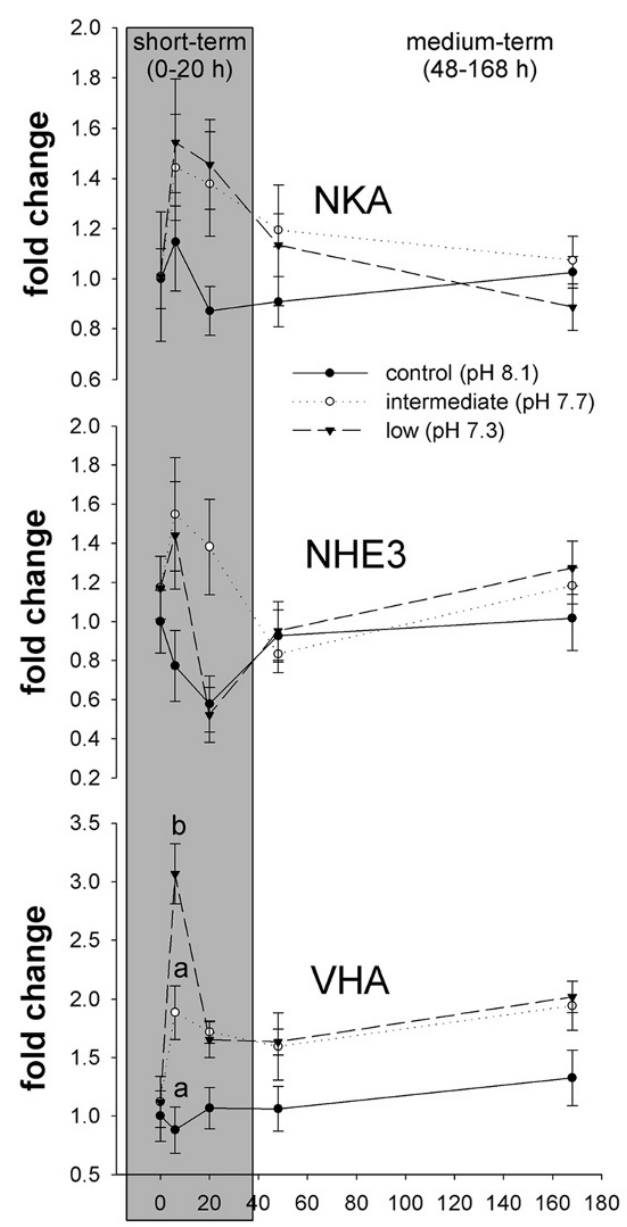

time (h)

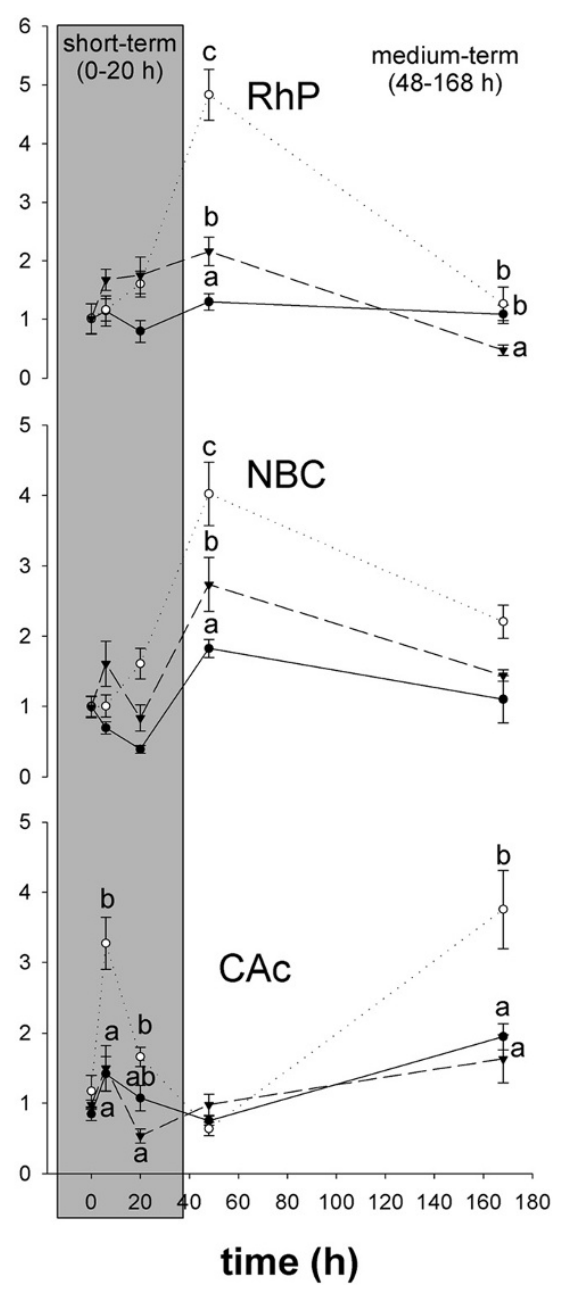

Figure 8 Effects of acidification on transcript abundance of gill acid-base transporters. Branchial mRNA expression levels of acid-base relevant candidates including $\mathrm{Na}^{+} / \mathrm{K}^{+}$-ATPase $(\mathrm{NKA}), \mathrm{Na}^{+} / \mathrm{H}^{+}$-exchanger $3(\mathrm{NHE} 3), \mathrm{V}$-type- $\mathrm{H}^{+}$-ATPase $(\mathrm{VHA})$, Rhesus protein $(\mathrm{RhP}), \mathrm{Na}^{+} / \mathrm{HCO}_{3}{ }^{-}$ co-transporter (NBC) and cytosolic carbonic anhydrase (CAc) during exposure to different pH conditions including pH 8.1 (control), $\mathrm{pH} 7.7$ (intermediate) and pH 7.3 (low) along the time course of $168 \mathrm{~h}$. Expression of the gene candidates are normalized to UBC and presented as relative change. The exposure period was separated into a short-term (grey) and medium-term (white) acclimation period. Letters indicate significant differences between $\mathrm{pH}$ treatments $(p<0.05)$. Bars represent mean \pm SE $(n=3$; with the average of 2 animals from each replicate).

$0.2 \mathrm{pH}$ units below control levels is sufficient to achieve sufficient gas transport via the blood pigment hemocyanin under acidified conditions in this less active cephalopod species. However, for the squid $S$. lessoniana a full compensation of extracellular $\mathrm{pH}$ was evident after $20 \mathrm{~h}$ during exposure to acidified conditions $(\mathrm{pH}$ 7.3). It has been hypothesized that more sluggish cephalopod species like cuttlefish and octopods may not rely on $\mathrm{pH}$ dependent oxygen transport to the same extent as more active pelagic squid species $[3,4,6]$. Interestingly, blood $\mathrm{HCO}_{3}{ }^{-}$levels in S. officinalis increased by approximately $7.5 \mathrm{mM}$ within 48 $\mathrm{h}$ in response to $0.6 \mathrm{kPa} \mathrm{CO}$ exposure whereas in this study blood $\left[\mathrm{HCO}_{3}{ }^{-}\right]$was only increased by $2 \mathrm{mM}$ when exposed to a similar acidification level. This indicates the presence of differential $\mathrm{pH}$ buffering/regulatory mechanisms, including non-bicarbonate buffering and $\mathrm{H}^{+}$extrusion mechanisms among cephalopods. Non-bicarbonate buffer values determined for squid species ranged between $5 \mathrm{mmol} \mathrm{l}^{-1} \mathrm{pH}$ unit $^{-1}$ (Illex illecebrosus), $5.8 \mathrm{mmol} \mathrm{l}^{-1} \mathrm{pH}$ unit $^{-1}$ (Loligo pealei) and $4.7 \mathrm{mmol} \mathrm{l}^{-1} \mathrm{pH}$ unit $^{-1}$ (S. lessoniana) whereas those determined for cuttlefish, $S$. officinalis were $10 \mathrm{mmol} \mathrm{l}^{-1}$ $\mathrm{pH}$ unit $^{-1}[3,6,39]$ indicating an even lower $\mathrm{HCO}_{3}{ }^{-}$ independent buffering potential in squid species. According to these observations it can be suggested that control of extracellular $\mathrm{pH}$ in squids is likely to be attributed to efficient $\mathrm{H}^{+}$extrusion mechanisms. Earlier studies using fish and crustaceans demonstrated that the compensation of acid-base disturbances elicited by hypercapnia is always associated with significant export of proton equivalents $[36,40,41]$. This feature 
is particularly important, as $\mathrm{HCO}_{3}{ }^{-}$formation through the hydration of $\mathrm{CO}_{2}$ is always accompanied with the generation of $\mathrm{H}^{+}$. Thus, on the long run organisms that stabilize blood $\mathrm{pH}$ via increased $\mathrm{HCO}_{3}{ }^{-}$accumulation require $\mathrm{H}^{+}$secretion mechanisms as well. These observations are in line with the results of the present work demonstrating that environmental acidification stimulates expression of branchial acid-base transporters involved in $\mathrm{HCO}_{3}{ }^{-}(\mathrm{NBC}, \mathrm{CA})$ and $\mathrm{H}^{+}$transport (VHA and $\mathrm{RhP}$ ). Although an increase of $\mathrm{VHA}$ in response to acidified conditions on both the protein and mRNA level has been demonstrated, no significant $(p=0.061)$ increases in branchial VHA enzyme activities were found. It can be suggested that despite a trend of increased VHA activity during short-term low $\mathrm{pH}$ acclimation, statistical analyses failed to prove this effect due to a relatively low experimental " $\mathrm{n}$ " (three experimental replicates with six biological replicates) which is always the limitation when working with non-model organisms. Nonetheless, whole animal observations and molecular findings suggest that besides $\mathrm{HCO}_{3}{ }^{-}$buffering $\mathrm{H}^{+}$secretion pathways across gill epithelia represent probably an even more important mechanism to compensate for acid-base disturbances in active squids. Thus, a special focus of the present work has been dedicated to a better understanding of branchial proton equivalent secretion mechanisms in ammonotelic cephalopods.

\section{Branchial acid-base regulatory machinery}

In convergence to fish and crustaceans, cephalopods evolved branchial ion regulatory epithelia, which are equipped with ion transporters including NKA, VHA and NBCe beneficial for coping with acid-base disturbances $[16,17,25,42,43]$. The present work further demonstrates that gene transcripts coding for $\mathrm{Na}^{+} / \mathrm{H}^{+}$exchanger 3 (NHE3) and Rh protein (RhP), which are essential for proton equivalent transport in vertebrates [27,28,44,45] are also expressed in the cephalopod gill. NKA-rich cells (NaRs) located in the ion-transporting inner epithelium of the 3 order lamellae of the cephalopod gill showed positive immunoreactivity for VHA (basolateral), NHE3 (apical) and RhP (apical) using antibodies specifically designed for this species. These polyclonal antibodies were designed against conserved regions of the respective protein, and western blot analyses of a previous study [10] and the present work demonstrated specific immunoreactivity with proteins in the predicted size range. Using in situ hybridization an earlier study demonstrated that an electrogenic $\mathrm{Na}^{+} / \mathrm{HCO}_{3}{ }^{-}$cotransporter (NBC) is also highly expressed in the ion-transporting epithelium of the cuttlefish (Sepia officinalis) gill [12]. Together with the results of the present work it can be suggested that this transporter represents an important player in branchial epithelia that mediates extracellular accumulation of
$\mathrm{HCO}_{3}^{-}$in cephalopods. Due to the lack of sequence information the existence and role of anion exchangers (e.g. AE1) which were demonstrated to contribute to acid-base homeostasis in teleosts [46] remains unexplored for cephalopods.

Interestingly, positive VHA immunoractivity was additionally found in pilaster (or pillar) cells spanning through the blood sinus between the inner and the outer epithelium. Little information exists regarding a potential function of pillar cells in ion-regulatory or respiratory processes. Pillar cells in the dogfish (Squalus acanthias) gill were demonstrated to represent an important cell type that may contribute to gas exchange. These pillar cells are characterized by high concentrations of extracellular membrane bound carbonic anhydrase (CA) IV summarized in [47]. This extracellular membrane bound CAIV has been suggested to facilitate the formation of $\mathrm{CO}_{2}$ from $\mathrm{HCO}_{3}{ }^{-}$in concert with basolateral VHA contributing to $\mathrm{CO}_{2}$ excretion across branchial epithelia in dogfish [48]. In Cephalopods carbonic anhydrase has been demonstrated to be associated with the inner iontransporting epithelium [11], but information regarding the expression of CA by pilaster cells is not available at present. However, it can be hypothesized that analogous to the situation in dogfish high concentrations of VHA associated with pillar cells may also support gas exchange by providing protons for the formation of $\mathrm{CO}_{2}$.

The subcellular localization of ion-transporters in squid gills is similar to that found in epidermal ionocytes of cephalopod embryonic stages [10,49]. Interestingly, ion regulatory epithelia in both, adults and embryonic stages seem to have a basolateral orientation of the VHA. This feature has been described for base-secreting type B intercalated cells in the mammalian kidney, and was mainly associated with base secretory processes in other vertebrate systems [50-52]. Although information is scarce for $\mathrm{pH}$ regulatory systems of invertebrates a recent study suggested the interplay of VHA, NKA, NHE and CA in the $\mathrm{NH}_{3} / \mathrm{NH}_{4}{ }^{+}$secretion mechanism of the freshwater planarian, Schmidtea mediterranea [53]. Similar to this early invertebrate the present work indicates that also in cephalopod molluscs acid-base regulation in branchial epithelia is associated with increased VHA and RhP protein and mRNA levels. As VHA can only pump $\mathrm{H}^{+}$out of the cell, with the catalytic (V1 complex) site located within the cytoplasm, it can be proposed that increased demands of VHA may be explained by two possibilities: i) extracellular $\mathrm{NH}_{4}{ }^{+}$ formation in the basolateral boundary layer to import ammonium ions via basolateral NKA and / or ii) local and timely control of blood $\mathrm{pH}$ homeostasis in the branchial blood sinus to maintain optimum conditions for gas exchange by hemocyanins. The latter, is particularly interesting, as the cephalopod gill has to simultaneously 
serve acid-base regulatory (excretory) and respiratory functions, which to some extend, must be connected due to morphological features of the cephalopod gill (see Figures 1 and 9). At the site of gas exchange and excretion, a substantial amount of free protons are removed from the blood due to $\mathrm{CO}_{2}$ diffusion across the respiratory epithelium into the seawater and via $\mathrm{NH}_{4}{ }^{+}$secretion across the ion-transporting epithelium. During transit of blood through the gills (between ctenidial artery and vein) up to $0.62 \mathrm{mM} \mathrm{l}^{-1} \mathrm{NH}_{4}{ }^{+}$is excreted indicating an equimolar loss in $\mathrm{H}^{+}$ions in Octopus dolfleini [54]. Furthermore, cannulation experiments using unrestrained squid demonstrated that during exercise an alkalosis occurs in venous blood due to an alkalizing effect of hemocyanin deoxygenation [2]. Although a fraction of protons of approximately $7^{*} 10^{-6} \mathrm{mM} \mathrm{l}^{-1}$ see [6] are bound to hemocyanin during deoxygenation and vice versa it is unlikely that the release of protons during oxygenation at the gills would compensate for the total loss of proton equivalents (e.g. $\mathrm{NH}_{4}{ }^{+}$) leading to a local alkalosis in branchial blood sinuses. Accordingly, it can be hypothesized that VHA located in basolateral membranes and pillar cells could potentially contribute to temporal and local $\mathrm{pH}$ homeostasis (during exercise/environmental hypercapnia), to optimize branchial $\mathrm{O}_{2}$ uptake and especially $\mathrm{CO}_{2}$ release via the highly $\mathrm{pH}$ sensitive hemocyanins (see Figure 9). This is very important as cephalopod hemocyanin appear to have an $\mathrm{O}_{2}$-dependent $\mathrm{CO}_{2}$ binding mechanisms that

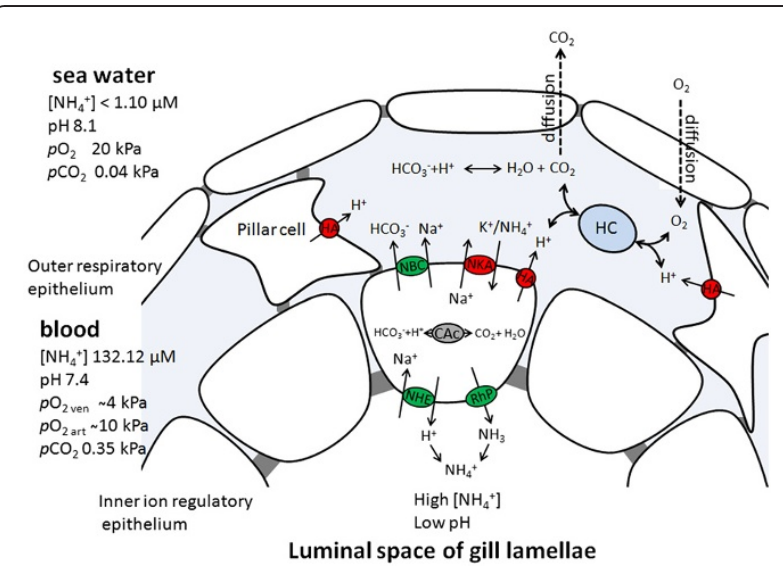

Figure 9 Hypothetical model for the coupling of acid-base regulation and gas exchange in the squid gill. Schematic illustration of the inner (ion-transporting) and the outer (respiratory) epithelium connected by pillar cells. lonocytes of the ion-transporting epithelium express $\mathrm{Na}^{+} / \mathrm{K}^{+}$-ATPase (NKA), V-type $\mathrm{H}^{+}$-ATPase $(\mathrm{HA}), \mathrm{Na}^{+} / \mathrm{H}^{+}$ exchanger 3 (NHE3), Rhesus protein (RhP) and $\mathrm{Na}^{+} / \mathrm{HCO}_{3}{ }^{-}$co-transporter (NBC) which are involved in $\mathrm{HCO}_{3}^{-}$buffering and $\mathrm{NH}_{4}^{+}$excretion. $\mathrm{NH}_{4}^{+}$is trapped in the acidified tubular space of the $3^{\circ}$ gill lamellae whereas the outer respiratory epithelium is spatially separated from the excretory epithelium. HA expressed in pillar cells may contribute to blood pH homeostasis to support gas transport by the highly $\mathrm{pH}$ sensitive hemocyanin ( $\mathrm{HC}$. is particularly well developed in active squid species [55]. Unfortunately hemocyanin functioning in cephalopods mainly focused on $\mathrm{O}_{2}$ release and $\mathrm{CO}_{2}$ uptake/release in tissues, leaving the characteristics of $\mathrm{O}_{2}$ uptake, and particularly $\mathrm{CO}_{2}$ release mechanisms in branchial epithelia underrepresented [56]. Thus, future studies are needed to address the acid-base parameters at the site of gas exchange, (within gills) in combination with a more detailed characterization of potential pillar cell functions.

\section{Branchial $\mathrm{NH}_{3} / \mathrm{NH}_{4}{ }^{+}$transport mechanisms}

The dual function of the cephalopod gill in gas exchange and extracellular acid-base regulation is achieved by different epithelia in this organ (depicted in Figures 1 and 9). The thin outer epithelium is believed to be involved in gas exchange by diffusive processes, whereas the inner ion-transporting epithelium is responsible for active transport of acid-base equivalents [11-13]. Apical localization of RhP and NHE3 in the inner transporting epithelium supports the hypothesis that the cephalopod gill is a major site of $\mathrm{NH}_{4}{ }^{+}$excretion. Earlier studies demonstrated that in various cephalopod species the largest fraction of ammonia produced through amino acid metabolism is excreted via branchial epithelia $[14,54]$. Blood $\mathrm{NH}_{4}{ }^{+} / \mathrm{NH}_{3}$ concentrations determined for octopus [54], cuttlefish [14] and squid [57] range from 100 to $500 \mu \mathrm{mol}^{-1}$ and are comparable to those determined for $S$. lessoniana in the present work $\left(132.11 \pm 37.79 \mu \mathrm{mol} \mathrm{l} \mathrm{l}^{-1} ; \mathrm{n}=4\right)$. Earlier studies hypothesized that ammonia is excreted as ammonia (NH3) accompanied with an excretion of protons to form the ammonium ion $\left(\mathrm{NH}_{4}^{+}\right)[14,54]$. This net export of proton equivalents further suggests that $\mathrm{NH}_{4}{ }^{+}$excretion represents an important mechanism that contributes to acid-base balance in cephalopods. Interestingly, the cephalopod gill shows many morphological and functional similarities to the collecting duct of the mammalian kidney, where $\mathrm{NH}_{4}{ }^{+}$ is transported to the luminal space via $\mathrm{Rh}$ glycoproteins and V-type $\mathrm{H}^{+}$-ATPase [45]. In the cephalopod gill, the semi-tubular structure of the $3^{\circ}$ gill lamellae creates a luminal space into which $\mathrm{NH}_{4}{ }^{+}$is secreted by the interplay of RhP and NHE3 (Figure 9). The involvement of NHE3 instead of VHA in this process is thermodynamically favored by the strong $\mathrm{Na}^{+}$gradient between cytosol $(30 \mathrm{mM})$ and seawater $(470 \mathrm{mM})$. In teleosts $\mathrm{Rh}$ proteins including Rhcg and Rhbg were identified as important players in branchial ammonia excretion pathways, as well [58]. The current model denotes the presence of Rhbg in basolateral membranes to facilitate the entry of $\mathrm{NH} 3$ into the cell, whereas Rhcg in combination with VHA and NHE2/3 is located in apical membranes. This interplay of $\mathrm{H}^{+}$and $\mathrm{NH} 3$ secretion provides an acid trapping mechanisms for apical $\mathrm{NH}_{4}{ }^{+}$secretion [58]. Accordingly it can be hypothesized that similar to the situation in teleosts and 
the mammalian kidney, cephalopods excrete ammonia across gill epithelia by trapping $\mathrm{NH}_{4}{ }^{+}$in the semi tubular space of the $3^{\circ}$ lamellae (Figure 9).

\section{Conclusion}

The present work demonstrated that cephalopods have evolved an efficient $\mathrm{pH}$ regulatory machinery in branchial epithelia. Acid-base transporters potentially involved in both, $\mathrm{HCO}_{3}{ }^{-}$accumulation and $\mathrm{H}^{+}$equivalent secretion were identified and localized in gill epithelia suggesting that this represents the major site for acid-base regulatory in cephalopods. Although significant $\mathrm{HCO}_{3}{ }^{-}$buffering capacities to control extracellular $\mathrm{pH}$ were only described for few marine species (fish, crustaceans and cephalopods) proton or proton equivalent secretion mechanisms may represent a more direct and ubiquitious $\mathrm{pH}$ regulatory pathway. Particularly the coupling of $\mathrm{H}^{+}$and $\mathrm{NH}_{3}$ secretion can be regarded a fundamental and evolutionary ancient pathway of excretion and acid-base regulation. The present work underlines the importance of $\mathrm{NH}_{4}{ }^{+}$based proton secretion via $\mathrm{RhP}$ that may contribute to well developed acid-base regulatory abilities in cephalopod molluscs.

The rapid compensation of $\mathrm{pHe}$ during exposure to acidified conditions is accompanied by a stimulation of branchial acid-base transporters on the protein and mRNA level, suggesting that maintenance of pHe represents a critical and energy consuming process for cephalopods to maintain vital functions. The present work further demonstrated that squids can tolerate short-term exposure without compromising aerobic energy metabolism while mediumterm (one week) exposure to acidified conditions evoked decreased metabolic rates and could even lead to mortality. These observations are in accordance to other studies using pelagic squids [1] but are contrasting to studies conducted on cephalopods that are able to switch to locomotory energy saving modes (e.g. cuttlefish) by burrowing in sediment or maintaining positive buoyancy by using their gas filled cuttlebones and fins [9]. Thus, this study indicates that energetic limitations may represent a critical feature that defines the degree of sensitivity towards seawater acidification. Pelagic squids that evolved a lifestyle at the edge of energetic limits due to high locomotory costs can be expected to be particularly sensitive to prolonged reallocations of energy towards compensatory processes despite their efficient proton equivalent secretion mechanisms. The identification of physiological principles that may lead to differential sensitivities even within one taxa represent an important task for future directions to better predict species sensitivities in times of rapid environmental change.

\section{Methods}

\section{Acidification experiments}

Sepioteuthis lessoniana with mantle lengths ranging from 8 to $10.5 \mathrm{~cm}$ were obtained from a local dealer in Keelung, Taiwan (ROC) in June 2013 and reared in a flow through system (6000 l total volume, nitrification filter, salinity $29-30$, temperature $29^{\circ} \mathrm{C}$, constant $12 \mathrm{~h}$ dark: $12 \mathrm{~h}$ light cycle) at the Jiao-Shi marine station of the Institute of Cellular and Organismic Biology, Academia Sinica. The natural seawater was pumped directly from coastal waters off the east coast of Taiwan, which is the natural habitat of $S$. lessoniana to the culturing facilities of the marine station. Animals were fed twice per day with live Palaemon shrimps (approximately 20\% of squid body mass). For the $\mathrm{CO}_{2}$ perturbation experiment a total of 90 animals were used and distributed into nine $300 \mathrm{l}$ tanks (10 animals per tank). The nine tanks, with three replicate tanks for each $\mathrm{pH}$ treatment were connected to a flow through system providing filtered, natural seawater. Flow rates were adjusted to approximately 3 $1 \mathrm{~min}^{-1}$ to guarantee high water quality inside the test aquaria. A light regime with a $12 \mathrm{~h}: 12 \mathrm{~h}$ light/dark-cycle was chosen. The aquaria were continuously equilibrated with the appropriate gas mixtures $\mathrm{pH} 8.1, \mathrm{pH} 7.7$ and $\mathrm{pH}$ 7.3) using a continuous $\mathrm{pH}$-stat system ( $\mathrm{pH}$ controller, MACRO) that controlled the addition of $\mathrm{CO}_{2}$ into the seawater, and aquaria were additionally continuously aerated with air $\left(\mathrm{O}_{2}\right.$ saturation $\left.>90 \%\right)$. Specific seawater conditions for the various incubations are given in Table 1 . Temperature, $\mathrm{pH}$ (NBS scale) and salinity were monitored on a daily basis. $\mathrm{pH}_{\mathrm{NBS}}$ was measured with a WTW 340i meter and WTW SenTix 81 electrode calibrated daily with Radiometer IUPAC precision $\mathrm{pH}_{\mathrm{NBS}}$ buffers 7.00 and 10.00 (S11M44, S11 M007) to monitor the experiment and to adjust the $\mathrm{pH}$-stat system. Additionally, water ammonia concentrations were determined every two to three days and levels were maintained $<5.55 \mu \mathrm{mol} \mathrm{l}^{-1}$. Total dissolved inorganic carbon $\left(C_{\mathrm{T}}\right)$ was measured in triplicate $(100 \mu \mathrm{L}$ each) using a Corning 965 carbon dioxide analyzer (Olympic Analytical Service (OAS),

Table 1 Seawater physiochemical parameters during the $168 \mathrm{~h} \mathrm{pH}$ perturbation experiment including pH (NBS scale), $\mathrm{CO}_{2}$ partial pressure $\left(p \mathrm{CO}_{2}\right)$, total $\mathrm{CO}_{2}\left(\mathrm{TCO}_{2}\right)$, total alkalinity (TA), salinity (Sal) and temperature (Temp)

\begin{tabular}{|c|c|c|c|c|c|c|}
\hline Treatment & $\mathrm{pH}_{\mathrm{NBS}}$ & $\begin{array}{l}\mathrm{pCO} 2 \\
\mu a t m\end{array}$ & $\begin{array}{l}\text { TCO2 } \\
\mathrm{mM}\end{array}$ & $\begin{array}{l}\text { TA } \\
\mathrm{mM}\end{array}$ & SAL & $\operatorname{Temp}^{\circ} \mathrm{C}$ \\
\hline $\mathrm{pH} 8.1$ & $8.06 \pm 0.002$ & $624.71 \pm 11.90$ & $2.27 \pm 0.04$ & $2.51 \pm 0.05$ & $29.89 \pm 0.19$ & $28.63 \pm 0.03$ \\
\hline $\mathrm{pH} 7.7$ & $7.72 \pm 0.019$ & $1585.59 \pm 253.20$ & $2.47 \pm 0.15$ & $2.56 \pm 0.14$ & $29.44 \pm 0.19$ & $28.71 \pm 0.06$ \\
\hline pH 7.3 & $7.34 \pm 0.017$ & $4134.16 \pm 168.76$ & $2.52 \pm 0.12$ & $2.47 \pm 0.12$ & $29.56 \pm 0.19$ & $28.75 \pm 0.08$ \\
\hline
\end{tabular}


Malvern, U.K.). Seawater carbonate chemistry speciation was calculated from $\mathrm{C}_{\mathrm{T}}$ and $\mathrm{pH}_{\mathrm{NBS}}$ with the software CO2SYS [59] using the dissociation constants of Mehrbach et al. [60] as refitted by Dickson \& Millero [61]. Along the incubation time of $168 \mathrm{~h}$, extracellular acid-base parameters were determined, and tissue samples were taken and quickly shock frozen in liquid nitrogen for gene expression and protein analyses. Sampling and measurements were carried out at five different time points $(0,6,20,48$, and $168 \mathrm{~h})$. For each $\mathrm{pH}$ treatment $(\mathrm{pH}$ 8.1: control; $\mathrm{pH}$ 7.7: intermediate and $\mathrm{pH}$ 7.3: low) three independent replicate tanks were used leading to a total number of nine experimental tanks. At each sampling time point two animals from every experimental tank were sampled, and thus biological replication was $n=6$. For statistical analyses the two animals from each replicate tank were averaged leading to a statistical $\mathrm{n}=3$. The experimental protocols were approved by the National Taiwan Normal University Institutional Animal Care and Utilization Committee (approval no.: 101005).

\section{Metabolic rates and ammonia excretion}

Determination of metabolic and ammonia $\left(\mathrm{NH}_{4}{ }^{+}\right)$excretion rates were determined at the $20 \mathrm{~h}$ and $168 \mathrm{~h}$ time points. Sepiotheuthis lessoniana from the $\mathrm{pH}$ experiments were starved overnight $(12 \mathrm{~h})$ and were gently transferred to glass respiration chambers with a volume of $4 \mathrm{~L}$ containing $0.2 \mu \mathrm{m}$ filtered seawater equilibrated with the appropriate $p \mathrm{CO}_{2}$ level. The digestion process in pelagic squids is finished within 2-6h [62] and the starvation time of $12 \mathrm{~h}$ is sufficient to prevent effects on metabolic rates due to digestion processes [63]. Respiration chambers were closed, and oxygen saturation was measured continuously (once every $30 \mathrm{~s}$ ) for $20-30 \mathrm{~min}$ at $28-29^{\circ} \mathrm{C}$ using oxygen sensors (PreSens sensor spots, type PSt3) placed in the lid of respiration chambers, connected to an OXY-4 mini multichannel fiber optic oxygen transmitter (PreSens, Regensburg, Germany). The sensors were calibrated according to the manufacturer's instructions. Preliminary experiments demonstrated that the ventilatory current of the animal could sufficiently mix the water inside the respiration chamber and oxygen concentration decreased linearly. Animal fresh mass was determined on a precision scale after all water was removed from the mantle cavity. When oxygen concentration reached the $75 \%$ air saturation level, animals were removed from the respiration chamber. Additionally, a separate glass chamber was incubated without animals to determine background readings of filtered seawater for ammonium excretion and respiration of bacteria. Bacterial respiration was $3.35 \pm 3.88 \mu \mathrm{mol} \mathrm{O} \mathrm{O}_{2} \mathrm{~h}^{-1}$ compared to average oxygen consumption by squids $(400.67 \pm 161.16 \mu \mathrm{mol}$ $\mathrm{O}_{2} \mathrm{~h}^{-1}$ ) leading to less than $1 \%$ of animal respiration. For calculation of oxygen consumption rates, the linear decrease in oxygen concentration during measuring intervals between $10 \mathrm{~min}$ after start and the end of the measurement period was considered. Oxygen consumption rates $\left(\mathrm{MO}_{2}\right)$ are expressed as $\mu \mathrm{mol} \mathrm{O} \mathrm{O}_{\mathrm{FM}}{ }^{-1} \mathrm{~h}^{-1}$.

Ammonium excretion rates were determined from $\mathrm{NH}_{4}{ }^{+}$ concentration measurements prior to and following incubation of squids for respiration measurements. Before and after closing the respiration chambers $10 \mathrm{ml}$ of seawater (stock) were sampled. For $\mathrm{NH}_{4}{ }^{+}$determinations a $100 \mu \mathrm{L}$ subsample was taken from the stock and $25 \mu \mathrm{L}$ of reagent containing orthophthaldialdehyde, sodium sulphite and sodium borate was added [64]. Samples were then incubated for $2 \mathrm{~h}$ at room temperature in the dark until fluorescence was determined at an excitation and emission wavelength of 360 and $422 \mathrm{~nm}$, respectively, using a microplate reader (Molecular Device, Spectra Max, M5). Ammonia $\left(\mathrm{NH}_{3}\right)$ was not measured as $\mathrm{NH}_{3}$ concentrations are negligible at $\mathrm{pH}$ values of $8.0-7.1(0.2-2 \%$ of total ammonium/ammonia, [65]. $\mathrm{NH}_{4}{ }^{+}$concentrations were determined in triplicates and excretion rates were expressed as $\mu \mathrm{mol} \mathrm{NH}{ }_{4}{ }^{+} \mathrm{g}_{\mathrm{FM}}{ }^{-1} \mathrm{~h}^{-1}$. Blood $\mathrm{NH}_{4}{ }^{+}$concentrations of four control animals were determined with the same method. This method is suitable for $\mathrm{NH}_{4}{ }^{+}$determinations in blood samples as it is specific to $\mathrm{NH}_{4}{ }^{+}$and insensitive to amino acids and proteins [64].

\section{Extracellular acid-base status}

Blood samples were collected from the vena cava via a gas-tight Hamilton syringe by dissecting the funnel and mantle from the ventral side. Determination of $\mathrm{pH}_{\mathrm{e}}$ was performed in $500 \mu \mathrm{l}$ samples inside a temperature controlled water bath $\left(29^{\circ} \mathrm{C}\right)$ using a microelectrode (WTW Mic-D) and a WTW pHi $340 \mathrm{pH}$ meter (precision \pm 0.01 units) that was calibrated with Radiometer precision buffers 7 and 10 (S11M44, S11 M007). For blood cell disposal, withdrawn blood was centrifuged for $30 \mathrm{~s}$ (6000 rpm) using a minifuge (Spectrafuge, Labnet International INC.). The supernatant was transferred into a new sample tube for the determination of total dissolved inorganic carbon $\left(C_{\mathrm{T}}\right) .\left(C_{\mathrm{T}}\right)$ was determined in duplicates $(100 \mu \mathrm{L}$ each) via a Corning 965 carbon dioxide analyzer (precision $\pm 0.1 \mathrm{mmol} \mathrm{L}^{-1}$; Olympic Analytical Service, England) that was calibrated by generating a sodium bicarbonate standard curve with a fresh dilution series of 20, 10, 5, 2.5 and $1.25 \mathrm{mM}$ bicarbonate in distilled water. Carbonate system speciation (i.e. $p \mathrm{CO}_{2},\left[\mathrm{HCO}_{3}^{-}\right]$) within the coelomic fluid of $S$. lessoniana was calculated from extracellular $\mathrm{pH}\left(\mathrm{pH}_{\mathrm{e}}\right)$ and $\left(C_{\mathrm{T}}\right)$ measurements according to the Henderson-Hasselbalch equation

$$
\begin{aligned}
& p \mathrm{CO}_{2}=C \mathrm{~T}\left(\alpha\left(10^{\left(\mathrm{pH}^{-p k 1^{\prime}}\right)}+1\right)\right)^{-1} \\
& \mathrm{e}\left[\mathrm{HCO}_{3}^{-}\right]=C \mathrm{~T}-\left(\alpha p \mathrm{CO}_{2}\right)
\end{aligned}
$$

where $\alpha\left(0.039 \mu \mathrm{mol} \mathrm{L} \mathrm{L}^{-1} \mathrm{~Pa}\right)$ is the solubility coefficient of $\mathrm{CO}_{2}$ in seawater and $p K_{1}^{\prime}$ (5.94) the dissociation 
constant of carbonic acid at a salinity of 30 , and a temperature of $29^{\circ} \mathrm{C}$ [66].

\section{Immunohistochemistry and western blot analyses}

For immunohistochemistry tissues were fixed by direct immersion for $24 \mathrm{~h}$ in Bouin's fixative followed by rinses in $75 \%$ ethanol. Samples were fully dehydrated in a graded ethanol series and embedded in Paraplast (Paraplast Plus, Sigma, P3683). Sections of $4 \mu \mathrm{m}$ were cut on a Leica RM2265 microtome, collected on polyL-lysine-coated slides. The slides were deparaffinized in Histoclear $\mathrm{II}^{\circ}$ for $10 \mathrm{~min}$ and passed through a descending alcohol series $(100 \%, 95 \%, 90 \%, 70 \%$, and $50 \%$ for $5 \mathrm{~min}$ each). Slides were washed in phosphate- buffered saline (PBS), pH 7.3. Subsequently, samples were transferred to a PBS solution containing $5 \%$ bovine serum albumin (BSA) for $30 \mathrm{~min}$ to block non-specific binding. The primary antibodies, a rabbit polyclonal antibody $\mathrm{H}-300$, raised against the human $\alpha$ subunit of the $\mathrm{Na}^{+} / \mathrm{K}^{+}$-ATPase (NKA) (Santa Cruz Biotechnology, INC) and Sepioteuthis lessoniana specific polyclonal antibodies raised against part of the carboxyl-terminal region (IYRVRKVGYDEQ FIMSY) of $\mathrm{Na}^{+} / \mathrm{H}^{+}$-exchanger3 (NHE3), the subunit A region (SYSKYTRALDEFYDK) of the $\mathrm{V}$-type- $\mathrm{H}^{+}$-ATPase (VHA) for more detail see [10] and the Rhesus protein (RhP) (antibody designed against the synthetic peptideTRAGYQEFKW) were diluted in PBS (1:50-100) and placed in small droplets of $200 \mu \mathrm{l}$ onto the sections, and incubated for $12 \mathrm{~h}$ at $4^{\circ} \mathrm{C}$ in a wet chamber. To remove unbound antibodies, the sections were then washed $(3 \times 5 \mathrm{~min})$ in PBS and incubated for $1 \mathrm{~h}$ with small droplets $(200 \mu \mathrm{l})$ of secondary antibody, antimouse Alexa Fluor 488 or anti- rabbit Alexa Fluor 568 (Invitrogen) (dilution 1:250). To allow double-color immunofluorescence staining, one of the polyclonal antibodies was directly labeled with Alexa Fluor dyes using the Zenon antibody labeling kit (Molecular Probes, Eugene, OR, USA). After rinses in PBS $(3 \times 5 \mathrm{~min})$, sections were examined with a fluorescence microscope (Zeiss imager A1) equipped with an appropriate filter set.

For immunoblotting, $15 \mu \mathrm{L}$ of crude extracts from gill tissues were used. Proteins were fractionated by SDS-PAGE on $10 \%$ polyacrylamide gels, according to Lämmli [67], and transferred to PVDF membranes (Millipore), using a tank blotting system (Bio-Rad). Blots were pre-incubated for $1 \mathrm{~h}$ at room temperature in TBS-Tween buffer (TBS-T, $50 \mathrm{mM}$ Tris - $\mathrm{HCl}, \mathrm{pH}$ 7.4, $0.9 \%$ (wt $/ \mathrm{vol}$ ) NaCl, $0.1 \%$ (vol $/ \mathrm{vol}$ ) Tween 20 ) containing $5 \%$ (wt/vol) blocking reagent (Roche, Mannheim, Germany). Blots were incubated with the primary antibody (see previous section) diluted $1: 250-500$ at $4^{\circ} \mathrm{C}$ overnight. After washing with TBS-T, blots were incubated for 2 $h$ with horseradish conjugated goat anti-rabbit IgG antibody (diluted 1:1,000-2,000, at room temperature;
Amersham Pharmacia Biotech). Protein signals were visualized by using the enhanced chemiluminescence system (ECL, Amersham Pharmacia Biotech) and recorded using Biospectrum 600 imaging system (UVP, Upland, CA, USA). Signal intensity was calculated using the free software "Image J" e.g. [68].

\section{Enzyme activity}

ATPase activity was measured in crude extracts in a coupled enzyme assay with pyruvate kinase (PK) and lactate dehydrogenase (LDH) by using the method of Schwartz et al. [69]. Crude extracts were obtained by quickly homogenizing the tissue samples using a tissue lyzer (Quiagen) in 10 volumes of ice-cold buffer containing $50 \mathrm{mM}$ imidazole, $\mathrm{pH}$ 7.5, $250 \mathrm{mM}$ sucrose, $1 \mathrm{mM}$ EDTA, $5 \mathrm{mM} \beta$-mercaptoethanol, $0.1 \%(\mathrm{w} / \mathrm{v})$ deoxycholate, proteinase inhibitor cocktail from Sigma-Aldrich (catalogue no. P8340). Cell debris was removed by centrifugation for $10 \mathrm{~min}$ at $1000 \mathrm{~g}, 4^{\circ} \mathrm{C}$. The supernatant was used as a crude extract. The reaction was started by adding $2 \mu \mathrm{l}$ of the sample homogenate to the reaction buffer containing $100 \mathrm{mM}$ imidazole, pH 7.5, $80 \mathrm{mM} \mathrm{NaCl}, 20 \mathrm{mM} \mathrm{KCl}$, $5 \mathrm{mMMgCl}_{2}, 5 \mathrm{mM}$ ATP, $0.24 \mathrm{mM} \mathrm{Na}$-(NADH 2 ), $2 \mathrm{mM}$ phosphoenolpyruvate, and about $12 \mathrm{U} / \mathrm{ml} \mathrm{PK}$ and $17 \mathrm{U} / \mathrm{ml}$ $\mathrm{LDH}$ in a PK/LDH enzyme mix (Sigma-Aldrich). The oxidation of NADH coupled to the hydrolysis of ATP was followed photometrically at $29^{\circ} \mathrm{C}$ in a temperature controlled plate reader (Molecular Device, Spectra Max, M5), over a period of $15 \mathrm{~min}$, with the decrease of extinction being measured at $\lambda=339 \mathrm{~nm}$. The fraction of $\mathrm{Na}^{+} / \mathrm{K}^{+}$-ATPase or $\mathrm{H}^{+}$-ATPase activity in total ATPase (TA) activity was determined by the addition of 2 $\mu$ l ouabain (5 $\mathrm{mM}$ final concentration) or bafilomycin (Bafilomycin A1, Sigma-Aldrich) $(10 \mu \mathrm{M}$ final concentration) to the assay, respectively. The concentrations of inhibitors applied were demonstrated to be sufficient to fully inhibit the NKA [70] and VHA [71], respectively. Each sample was measured in six replicates (3 with inhibitor dissolved in DMSO and 3 with DMSO). Enzyme activity was calculated by using an extinction coefficient for NADH of $\varepsilon=6.31 \mathrm{mM}^{-1} \cdot \mathrm{cm}^{-1}$ and given as micromoles of ATP consumed per gram tissue fresh mass $\left(g_{\mathrm{FM}}\right)$ per hour.

\section{Preparation of mRNA}

Gill tissues (without branchial gland) were homogenized in Trizol reagent (Invitrogen, Carlsbad, CA, USA) using a Tissue lyser (Quiagen). Total RNA was extracted from the aqueous phase after addition of chloroform to Trizol homogenates and purified by addition of isopropanol. DNA contamination was removed with DNase I (Promega, Madison, WI, USA). The mRNA for the RT-PCR was obtained with a QuickPrep Micro mRNA Purification Kit (Amersham Pharmacia, Piscataway, NJ, USA) according 
Table 2 Primers used for qRT-PCR

\begin{tabular}{|c|c|c|c|c|}
\hline Gene name & Abbreviation & Primer sequence & Amplicon size (bp) & Accession numbers \\
\hline \multirow[t]{2}{*}{ Sodium-hydrogen exchanger 3} & NHE3 & F 5'- GGCTGTCTTCCAAGAAATGGGTGT -3' & 168 & KJ451615 \\
\hline & & R 5'- AAGAACTTGGCAACACCAAGAGCG -3' & & \\
\hline \multirow[t]{2}{*}{ Vacuolar-type $\mathrm{H}+-$-ATPase } & $\mathrm{VHA}$ & F 5'- ACGTGAGGGCAGTGTCAGTATTGT -3' & 161 & ADM67602.1 \\
\hline & & R 5'- TGATCAGCCAGTTGATGGAAGGGA -3' & & \\
\hline \multirow[t]{2}{*}{$\mathrm{Na}+, \mathrm{K}+-$ ATPase } & NKA & F 5'- CCGTGCTGAATTTAAGGCAGGTCA -3' & 83 & GQ153672.1 \\
\hline & & R 5'- GCAAAGCTGATTCAGAAGCGTCAC -3' & & \\
\hline \multirow[t]{2}{*}{ Rhesus protein } & $\mathrm{RhP}$ & F 5'-GCACAAAGGAAAGCTGGACATGGT-3' & 179 & KJ451616 \\
\hline & & R 5'-AATGATACCAGCCACCACTCCGA-3' & & \\
\hline \multirow[t]{2}{*}{ Sodium-bicarbonate cotransporter } & NBC & F 5'-AATTCGCTGCATGATTGTCCGTCC-3' & 188 & HM157263.1 \\
\hline & & R 5'-TTCCGGAGAACTGACGACCGATTT-3' & & \\
\hline \multirow[t]{2}{*}{ Cytosolic Carbonic anhydrase } & CAC & F 5'-GTGAAGCCAACATGGAAGTC-3' & 108 & KJ451614 \\
\hline & & R 5'-GCAGTTTGTAAGGAGTTGTCTC-3' & & \\
\hline \multicolumn{5}{|l|}{ Reference gene } \\
\hline \multirow[t]{2}{*}{ Ubiquitin-conjugated enzyme } & UBC & F 5'- ATGCAGATGGCAGTATTTGCCTGG -3' & 127 & HM157280.1 \\
\hline & & R 5'- TTATTGGCTGGGCTGTTTGGGTTC -3' & & \\
\hline
\end{tabular}

$F$, forward primer; $R$, reverse primer.

to the supplier protocol. The amount of mRNA was determined by spectrophotometry (ND-2000, NanoDrop Technol, Wilmington, DE), and the mRNA quality was checked by running electrophoresis in RNA denatured gels. All mRNA pellets were stored at $-80^{\circ} \mathrm{C}$.

\section{Real-time quantitative PCR (qPCR)}

The mRNA expressions of target genes were measured by qPCR with the Roche LightCycler ${ }^{\circ} 480$ System (Roche Applied Science, Mannheim, Germany). Primers for all genes were designed using Primer Premier software (vers. 5.0; PREMIER Biosoft International, Palo Alto, CA). The sequences and primers were used in a previous study [10] and are depicted in Table 2. In addition to the previously cloned sequences of squid acid-base transporters a cytosolic carbonic anhydrase (CAc) sequence (KJ451614) was cloned from squid (S. lessoniana). PCRs contained $40 \mathrm{ng}$ of cDNA, 50 $\mathrm{nM}$ of each primer, and the LightCycler 480 SYBR Green I Master (Roche) in a final volume of $10 \mu \mathrm{l}$. All qPCR reactions were performed as follows: 1 cycle of $50^{\circ} \mathrm{C}$ for $2 \mathrm{~min}$ and $95^{\circ} \mathrm{C}$ for $10 \mathrm{~min}$, followed by 45 cycles of $95^{\circ} \mathrm{C}$ for $15 \mathrm{sec}$ and $60^{\circ} \mathrm{C}$ for $1 \mathrm{~min}$ (the standard annealing temperature of all primers). PCR products were subjected to a melting-curve analysis, and representative samples were electrophoresed to verify that only a single product was present. All primer pairs used in this PCR had efficiencies $>96 \%$. Control reactions were conducted with nuclease-free water to determine levels of background. Additionally, no PCR product was obtained by using DNAse I treated RNA samples as template demonstrating the success of the DNase I treatment. The standard curve of each gene was confirmed to be in a linear range with ubiquitin conjugated protein $(U B C)$ as reference genes. The expression of this reference gene has been demonstrated to be stable in cephalopods among ontogenetic stages and during $\mathrm{CO}_{2}$ treatments $[10,12]$.

\section{Statistical analyses}

Statistical analyses were performed using Sigma Stat 3.0 (Systat) software. Statistical differences between $\mathrm{pH}$ treatments were analyzed by two-way and one-way ANOVA followed by Tukey's post-hoc test. Data sets were normally distributed (Kolmogorov-Smirnov test). Equal variance was tested using the Levene median test. The significance level was set to $\mathrm{p}<0.05$.

\section{Additional file}

Additional file 1: Figure S1. Negative controls for immunohistochemical analyses.

\section{Competing interests}

The authors declare that they have no competing interests.

\section{Authors' contributions}

$\mathrm{MYH}, \mathrm{PPH}$ and $\mathrm{YCT}$ designed and conducted experiment, analyzed the data and compiled the manuscript. MYH conducted immunohistochemical experiments and analyzed the data. YJG and YCT carried out the molecular cloning studies. MS conducted metabolic rates and ammonia measurement and analyzed the data. JRL, RDC, PHS and YCC conducted $\mathrm{CO}_{2}$ perturbation experiments and sample preparation. All authors read and approved the final manuscript. 


\section{Acknowledgements}

This study was financially supported by the grants to Y. C. Tseng from the National Science Council, Taiwan, Republic of China (NSC 102-2321-B-003-002) and an Alexander von Humbold/National Science Council (Taiwan) grant awarded to M. H (NSC 102-2911-I-001-002-2) and M.S. (NSC 103-2911-I-001-506). We gratefully thank Mr. H. T. Lee (assistant of Institute of Cellular and Organismic Biology marine station) for his assistance to maintain experimental systems.

\section{Author details}

'Institute of Cellular and Organismic Biology, Academia Sinica, Taipei City, Taiwan. ${ }^{2}$ Department of Life Science, National Taiwan Normal University, Taipei City, Taiwan

Received: 18 March 2014 Accepted: 22 July 2014

Published: 6 August 2014

\section{References}

1. Rosa R, Seibel BA: Synergistic effects of climate-related variables suggest future physiological impairment in a top oceanic predator. Proc Natl Acad Sci 2008, 105:20776-20780

2. Pörtner H-O, Webber DM, Boutilier RG, O'Dor RK: Acid-base regulation in exercising squid (Illex illecebrosus, Loligo pealei). Am J Physiol Regul Integr Comp Physiol 1991, 261:R239-R246.

3. Gutowska MA, Melzner F, Langenbuch M, Bock C, Claireaux G, Pörtner H-O Acid-base regulatory ability of the cephalopod (Sepia officinalis) in response to environmental hypercapnia. J Comp Physiol B 2010, 180:323-335.

4. Pörtner HO: Coordination of metabolism, acid-base regulation and haemocyanin function in cephalopods. Mar Fresh Behav Physiol 1994 25:131-148.

5. Brix $\mathrm{O}$, Lykkeboe $\mathrm{G}$, Johansen $\mathrm{K}$ : The significance of the linkage between the Bohr and Haldane effects in cephalopod bloods. Respir Physiol 1981, 44:177-186.

6. Pörtner H-O: An analysis of the effects of $\mathrm{pH}$ on oxygen binding by squid (Illex illecebrosus, Loligo pealei) haemocyanin. J Exp Biol 1990, 150:407-424.

7. Pörtner $\mathrm{HO}$, Langenbuch $M$, Reipschläger $A$ : Biological impact of elevated ocean $\mathrm{CO}_{2}$ concentrations: lessons from animal physiology and earth history. J Oceanogr 2004, 60:705-718.

8. Melzner F, Gutowska MA, Langenbuch M, Dupont S, Lucassen M, Thorndyke MC, Bleich $\mathrm{M}$, Pörtner $\mathrm{H}-\mathrm{O}$ : Physiological basis for high $\mathrm{CO}_{2}$ tolerance in marine ectothermic animals: pre-adaptation through lifestyle and ontogeny? Biogeosciences 2009, 6:2313-2331.

9. Gutowska MA, Pörtner H-O, Melzner F: Growth and calcification in the cephalopod Sepia officinalis under elevated seawater $\mathrm{pCO}_{2}$. Mar Ecol Prog Ser 2008, 373:303-309.

10. Hu MY, Lee J-R, Lin L-Y, Shih T-H, Stumpp M, Lee M-F, Hwang P-P, Tseng YC: Development in a naturally acidified environment: $\mathrm{Na}^{+} / \mathrm{H}^{+}$-exchanger 3-based proton secretion leads to $\mathrm{CO}_{2}$ tolerance in cephalopod embryos. Front Zool 2013, 10:51-67.

11. Schipp R, Mollenhauer S, Boletzky S: Electron microscopical and histochemical studies of differentiation and function of the cephalopod gill (Sepia officinalis L.). Zoomorph 1979, 93:193-207.

12. Hu MY, Tseng Y-C, Stumpp M, Gutowska MA, Kiko R, Lucassen M, Melzner F: Elevated seawater $p \mathrm{CO}_{2}$ differentially affects branchial acid-base transporters over the course of development in the cephalopod Sepia officinalis. Am J Physiol Regul Integr Comp Physiol 2011, 300:R1100-R1114.

13. Hu MY, Sucré E, Charmantier-Daures M, Charmantier G, Lucassen M, Melzner F: Localization of ion regulatory epithelia in embryos and hatchlings of two cephalopods. Cell Tiss Res 2010, 441:571-583.

14. Donaubauer HH: Sodium- and potassium-activated adenosine triphosphatase in the excretory organs of Sepia officinalis (Cephalopoda). Mar Biol 1981, 63:143-150.

15. Perry SF, Gilmour KM: Acid-base balance and $\mathrm{CO}_{2}$ excretion in fish: Unanswered questions and emerging models. Respir Physiol Neurobiol 2006, 154:199-215.

16. Hwang PP, Perry SF: Ionic And Acid-Base Regulation. In Zebrafish, vol. 29. Edited by Perry SF, Ekker M, Farrel AP, Brauner CJ. London: Elsevier; 2010:311-344

17. Evans DH, Piermarini PM, Choe KP: The multifunctional fish gill: Dominant site of gas exchange, osmoregulation, acid-base regulation, and excretion of nitrogenous waste. Physiol Rev 2005, 85:97-177.
18. Henry RP, Lucu C, Onken H, Weihrauch D: Multiple functions of the crustacean gill: osmotic/ionic reglation, acid-base balance, ammonia excretion, and bioaccumulation of toxic metals. Front Physiol 2012, 3:431

19. Tresguerres M, Parks S, Sabatini SE, Goss GG, Luquet CM: Regulation of ion transport by $\mathrm{pH}$ and [HCO3-] in isolated gills of the crab Neohelice (Chasmagnathus) granulata. Am J Physiol Regul Integr Comp Physiol 2008, 294(3):R1033-R1043.

20. Cameron JN: Effects of hypercapnia on blood acid-base status, $\mathrm{NaC}$ fluxes and trans-gill potential in freshwater blue crabs, Callinectes sapidus. J Comp Physiol B 1978, 123:137-141.

21. Weihrauch D, Ziegler A, Siebers D, Towle DW: Active ammonia excretion across the gills of the green shore crab Carcinus maenas: participation of $\mathrm{Na}^{+} / \mathrm{k}^{+}$-ATPase, V-type $\mathrm{H}^{+}$-ATPase and functional microtubules. J Exp Biol 2002, 205:2765-2775

22. Martin M, Fehsenfeld S, Sourial MM, Weihrauch D: Effects of high environmental ammonia on branchial ammonia excretion rates and tissue Rh-protein mRNA expression levels in seawater acclimated Dungeness crab Metacarcinus magister. Comp Biochem Physiol A 2011, 160:267-277.

23. Stumpp M, Trübenbach K, Brennecke D, Hu MY, Melzner F: Resource allocation and extracellular acid-base status in the sea urchin Strongylocentrotus droebachiensis in response to $\mathrm{CO}_{2}$ induced seawater acidification. Aqua Toxicol 2012, 110-111:194-207.

24. Thomsen J, Melzner F: Moderate seawater acidification does not elicit long-term metabolic depression in the blue mussel Mytilus edulis. Mar Biol 2010, 157:2667-2676.

25. Fehsenfeld S, Weihrauch D: Differential acid-base regulation in various gills of the green crab Carcinus maenas: effects of elevated environmental pCO . Comp Biochem Physiol A 2012, doi: 10.1016/j.cbpa.2012.09.016.

26. Hu MY, Casties I, Stumpp M, Ortega-Martinez O, Dupont S: Energy metabolism and regeneration impaired by seawater acidification in the infaunal brittlestar Amphiura filiformis. J Exp Biol doi:10.1242/jeb.100024.

27. Wu S-C, Horng J-L, Liu S-T, Hwang PP, Wen Z-H, Lin C-S, Lin LY: Ammonium-dependent sodium uptake in mitochondrion-rich cells of medaka (Oryzias latipes) larvae. Am J Physiol Cell Physiol 2010, 298:C237-C250.

28. Nawata CM, Hirose S, Nakada T, Wood CM, Katoh A: Rh glycoprotein expression is modulated in pufferfish (Takifugu rubripes) during high environmental ammonia exposure. J Exp Biol 2010, 213:3150-3160.

29. Wagner CA, Devuyst O, Belge H, Bourgeois S, Houillier P: The rhesus protein Rhcg: a new perspective in ammonium transport and distal urinary acidification. Kidney Int 2011, 79:154-161.

30. Trübenbach K, Pegado MR, Seibel BA, Rosa R: Ventilation rates and activity levels of juvenile jumbo squid under metabolic suppression in the oxygen minimum zone. J Exp Biol 2013, 216:359-368.

31. Webber DM, O'Dor RK: Monitoring the metabolic rate and activity of free-swimming squid with telemetered jet pressure. J Exp Biol 1986, 126:205-224.

32. Boucher-Rodoni R, Mangold K: Comparative aspects of ammonia excretion in cephalopods. Malacologica 1988, 29:145-151.

33. Boucher-Rodoni R, Mangold K: Respiration and nitrogen excretion by the squid Loligo forbesi. Mar Biol 1989, 103:333-338.

34. O'Dor RK: Telemetered cephalopod energetics: swimming, soaring, and blimping. Integr Comp Biol 2002, 42:1065-1070.

35. O'Dor RK, Webber DM: Invertebrate athletes: trade-offs between transport efficiency and power density in cephalopod evolution. J Exp Biol 1991 160:93-112.

36. Heisler N: Acid-Base Regulation In Animals. Amsterdam: Elsevier Biomedical Press; 1986.

37. Claiborne JB, Evans DH: Acid-base balance and ion transfers in the spiny dogfish (Squalus acanthias) during hypercapnia - a role for ammonia excretion. J Exp Zool 1992, 261:9-17.

38. Toews DP, Holeton GF, Heisler N: Regulation of the acid-base status during environmental hypercapnia in the marine teleost fish Conger conger. J Exp Biol 1983, 107:9-20.

39. Lykkeboe $\mathrm{G}$, Johansen $\mathrm{K}: \mathrm{A}$ cephalopod approach to rethinking about the importance of the Bohr and Haldane effects. Pac Sci 1982, 36:305-313.

40. Heisler N: Acid-Base Regulation In Fishes. New York: Academic; 1984.

41. Cameron JN: Acid-Base Equilibria In Invertebrates. In Acid-Base Regulation In Animals. Edited by Heisler N. Amsterdam: Elsevier Biomedical Press; 1986.

42. Hwang $P P$, Lee $T H$, Lin $L Y$ : Ion regulation in fish gills: recent progress in the cellular and molecular mechanisms. Am J Physiol Regul Integr Comp Physiol 2011, 301(1):R28-R47. 
43. Charmantier G, Charmantier-Daures M: Ontogeny of osmoregulation in crustaceans: the embryonic phase. Am Zool 2001, 41:1078-1089.

44. Watanabe S, Niida M, Maruyama T, Kaneko T: $\mathrm{Na}+/ \mathrm{H}+$ exchanger isoform 3 expressed in apical membrane of gill mitochondrion-rich cells in Mozambique tilapia Oreochromis mossambicus. Fish Sci 2008, 74:813-821.

45. Bishop JM, Verlander JW, Lee H-W, Nelson RD, Weiner AJ, Handlogten ME, Weiner ID: Role of Rhesus glycoprotein, Rh B glycoprotein, in renal ammonia excretion. Am J Physiol Renal Physiol 2010, 299:F1065-F1077.

46. Lee YC, Yan JJ, Cruz SA LHJ, Hwang PP: Anion exchanger 1b, but not sodium-bicarbonate cotransporter $1 \mathrm{~b}$, plays a role in transport functions of zebrafish $\mathrm{H}^{+}$-ATPase-rich cells. Am J Physiol Regul Integr Comp Physiol 2011, 300:C295-C307.

47. Gilmour KM, Perry SF: Carbonic anhydrase and acid-base regulation in fish. J Exp Biol 2009, 212:1647-1661.

48. Gilmour KM, Bayaa M, Kenny L, McNeill B, Perry SF: Type IV carbonic anhydrase is present in the gills of spiny dogfish (Squalus acanthias). Am J Physiol Integr Comp Physiol 2007, 292:R556-R567.

49. Hu MY, Tseng Y-C, Lin L-Y, Chen P-Y, Charmantier-Daures M, Hwang PP, Melzner F: New insights into ion regulation of cephalopod molluscs: a role of epidermal ionocytes in acid-base regulation during embryogenesis. Am J Physiol Regul Integr Comp Physiol 2011, 301:1700-1709.

50. Wagner CA, Finberg KE, Breton S, Marshanski V, Brown D, Geibel JP: Renal vacuolar $\mathrm{H}^{+}$-ATPase. Physiol Rev 2003, 84:1263-1314.

51. Tresguerres M, Parks SK, Katoh F, Goss GG: Microtubule-dependent relocation of branchial $\mathrm{V}-\mathrm{H}^{+}$-ATPase to the basolateral membrane in the Pacific spiny dogfish (Squalus acanthias): a role in base secretion. J Exp Biol 2006, 209:599-609.

52. Piermarini PM, Evans DH: Immunochemical analysis of the vacuolar proton-ATPase B-subunit in the gills of a euryhaline stingray (Dasyatis sabina): effects of salinity and relation to $\mathrm{Na}^{+} / \mathrm{K}^{+}$-ATPase. J Exp Biol 2001, 204:3251-3259.

53. Weihrauch D, Chan AC, Meyer H, Döring C, Sourial MM, O'Donnell MJ: Ammonia excetion in the freshwater planarian Schmidtea mediterranea. J Exp Biol 2012, doi:10.1242/jeb.067942. J Exp Biol 2012, 215:3242-3253.

54. Potts WTW: Ammonia excretion in Octopus dolfeini. Comp Biochem Physiol 1965, 14:339-355

55. Lykkeboe $\mathrm{G}$, Brix O, Johansen $\mathrm{K}$ : Oxygen-linked $\mathrm{CO}_{2}$ binding independent of $\mathrm{pH}$ in cephalopod blood. Nature 1980, 287:330-331.

56. Brix O, Bardgard A, Cau A, Colosimo SGC, Giardina B: Oxygen-binding properties of cephalopod blood with special reference to environmental temperatures and ecological distribution. J Exp Zool 1989, 252:34-42.

57. Voight JR, Pörtner HO, O'Dor RK: A review of ammonia-mediated buoyancy in squids (Cephalopoda: Teuthoidea). Mar Fresh Behav Physiol 1994, 25:193-203.

58. Wright PA, Wood CM: A new paradigm for ammonia excretion in aquatic animals: role of Rhesus (Rh) glycoproteins. J Exp Biol 2009, 212:2303-2312.

59. Lewis E, Wallace DWR: Program developed for CO2 system calculations. Oak Ridge: Oak Ridge National Laboratory ORNL/CDIAC-105; 1998.

60. Mehrbach C, Culberso C, Hawley J, Pytkowic R: Measurement of apparent dissociation constants of carbonic acid in seawter at atmospheric pressure. Limnol Oceanogr 1973, 18:897-907.

61. Dickson A, Millero F: A comparison of the equilibrium constants for the dissociation of carbonic acid in seawater media. Deep Sea Res A 1987, 34:1733-1743

62. Lipiński MR: Changes in $\mathrm{pH}$ in the caecum of Loligo vulgaris reynaudii during digestion. S Afr J Mar Sci 2010, 9(1):43-51.

63. Katsanevakis S, Protopapas N, Miliou H, Verriopoulos G: Effect of temperature on specific dynamic action in the common octopus Octopus vulgaris (Cephalopoda). Mar Biol 2005, 146:733-738.

64. Holmes RM, Aminot A, Kérouel R, Hooker BA, Peterson BJ: A simple and precise method for measuring ammonium in marine and freshwater ecosystems. Can J Fish Aquat Sci 1999, 56(10):1801-1808.

65. Körner S, Das SK, Veenstra S, Vermaat JE: The effect of pH variation at the ammonium/ammonia equilibrium in wastewater and its toxicity to Lemna gibba. Aquat Bot 2001, 71:71-78.

66. Weiss RF: Carbon dioxide in water and seawater: the solubility of a non-ideal gas. Mar Chem 1974, 2:203-215.

67. Lämmli UK: Cleavage of structural proteins during the assembly of the head of Bacteriophage T4. Nature 1970, 227:680-685.

68. Schneider CA, Rasband WS, Eliceiri KW: NIH Image to ImageJ: 25 years of image analysis. Nat Methods 2012, 9:671-675.
69. Schwartz AA, Allen JC, Harigaya S: Possible involvement of cardiac $\mathrm{Na}^{+} / \mathrm{K}^{+}$-adenosine triphosphatase in the mechanism of action of cardiac glycosides. J Pharmacol Exp Ther 1969, 168:31-41.

70. Morris JF, Ismail-Beigi F, Jr BVP, Gati I, Lichtstein D: Ouabain-sensitive $\mathrm{Na}+, \mathrm{K}(+)-$ ATPase activity in toad brain. Comp Biochem Physiol A 1997, 118:599-606.

71. Dröse S, Altendorf K: Bafilomycins and concanamycins as inhibitors of V-ATPases and P-ATPases. J Exp Biol 1997, 200:1-8.

doi:10.1186/s12983-014-0055-z

Cite this article as: $\mathrm{Hu}$ et al:: Branchial $\mathrm{NH}_{4}{ }^{+}$-dependent acid-base transport mechanisms and energy metabolism of squid (Sepioteuthis lessoniana) affected by seawater acidification. Frontiers in Zoology 2014 11:55

\section{Submit your next manuscript to BioMed Central and take full advantage of:}

- Convenient online submission

- Thorough peer review

- No space constraints or color figure charges

- Immediate publication on acceptance

- Inclusion in PubMed, CAS, Scopus and Google Scholar

- Research which is freely available for redistribution

Submit your manuscript at www.biomedcentral.com/submit
C Biomed Central 